\title{
Linking species, traits and habitat characteristics of Collembola at European scale
}

Salmon S. ${ }^{1 *}$, Ponge J.F. ${ }^{1}$, Gachet S. ${ }^{2}$, Deharveng, L. ${ }^{3}$, Lefebvre N. ${ }^{1}$, Delabrosse F. ${ }^{1}$

${ }^{1}$ Muséum National d'Histoire Naturelle, CNRS UMR 7179, 4 avenue du Petit-Château, 91800 Brunoy, France

${ }^{2}$ Muséum National d'Histoire Naturelle, CNRS UMR 7205, 45 rue Buffon, 75005 Paris, France

${ }^{3}$ Aix-Marseille Université, Institut Méditerranéen de Biodiversité et d'Écologie Marine et Continentale, CNRS UMR 7263, Campus Saint-Jérôme, Case 421, 13397 Marseille Cedex 20, France

* Corresponding author: Muséum National d'Histoire Naturelle, UMR CNRS 7179, 4 Avenue du Petit-Château, 91800 Brunoy, France

Tel: +33 (0)1 604792 21. E-mail address: ssalmon@mnhn.fr 
3 Although much work has been done on factors which influence the patterning of species and

4 species trait assemblages in a variety of groups such as plants, vertebrates and invertebrates,

5 few studies have been realized at a broad geographic scale. We analyzed patterns of 6 relationships between species, species trait distribution/assembly, and environmental variables 7 from the west of Europe to Slovakia, Poland and Sweden. We created a database by compiling traits and occurrence data of European collembolan species, using literature and personal field studies embracing a large range of environmental gradients (vertical stratification, habitat closure, humus form, soil acidity and moisture, temperature, rainfall, altitude) over which Collembola are supposed to be distributed. Occurrences of the 58 best-documented species, environmental variables and species traits allowed us to (i) show which environmental variables impact the distribution of the 58 species at broad scale and (2) document to what extent environmental variables and species trait assemblages are related and which trends could be found in trait/environment relationships. The impact of vertical stratification, habitat closure, humus form, soil acidity, soil moisture, temperature, and to a lesser extent rainfall and altitude on species distribution, firstly revealed by indirect gradient analysis (correspondence analysis, CA), was further shown to be significant by direct gradient analysis (canonical correspondence analysis, CCA). RLQ analyses were performed to find linear combination of variables of table $\mathrm{R}$ (environmental variables) and linear combinations of the variables of table $\mathrm{Q}$ (species traits) of maximum covariance weighted by species occurrence 22 data contained in table L. RLQ followed by permutation tests showed that all tested environmental variables apparently contributed significantly to the assemblages of the twelve species traits studied. A convergence was observed between traits related to vertical 
1 (furcula, legs), presence of sensorial organs sensitive to air movements and light (e.g.

2 trichobothria and eye spots), spherical body, large body size, pigmentation (UV protection

3 and signalling) and sexual reproduction largely occur in epigeic and open habitats, while most

4 of woodland and edaphic habitats are characterized by short locomotory appendages, small

5 body size, high number of defense organs (pseudocelli), presence of post-antennal organs and

6 parthenogenesis. Climate and especially temperature exert an effect on the assemblage of

7 traits that are mostly present above-ground and in open habitats. The contribution of

8 combinations of some environmental variables to the occurrence of each species trait was

9 tested by linear, logistic or multinomial regression (Generalized Linear Models). Vertical

10 stratification, followed by temperature, played a dominant role in the variation of the twelve

11 studied traits. Relationships between traits and environment tested here shows that it is

12 possible to use some traits as proxies to identify potential ecological preferences or tolerances

13 of invertebrate species. However, a significant part of species distribution remained

14 unexplained, probably partly because some traits, like ecophysiological ones, or traits

15 involved in biotic interactions (e.g. competition) were unavailable. The present work is thus a

16 first step towards the creation of models predicting changes in collembolan communities.

17 Further studies are required to inform ecophysiological traits, in order to complete such models. Moreover the niche width of species will have to be determined.

Keywords: Collembola; environmental filtering; habitats; broad scale distribution; species

21 traits; species assemblages; sensory organs 
Identifying the main factors that drive the composition of communities and the distribution of species is a fundamental goal in community ecology and is of particular importance for predicting biodiversity responses to environmental changes (Belyea and Lancaster, 1999). Selection of species by habitat constraints (deterministic process) is one of the four classes of processes that influence patterns in the composition and diversity of species (Vellend, 2010). Functional traits, (named "traits" hereafter), are well-defined, measurable properties of organisms, used comparatively across species, and that strongly influence organismal performance (McGill et al., 2006). Focusing on the selection of species

11 functional traits rather than only on species identity, allows to (1) identify mechanisms implied in the distribution of species and in the dynamics of biodiversity, (2) understand the mechanisms that shape communities comprised of many species (3) identify general patterns and hence, help to predict potential changes in the composition of communities, and consecutive ecosystem functioning, following disturbance (McGill et al., 2006, Vellend, 2010). The use of functional traits of species allowed to understand species responses to varied disturbances such as fragmentation, land use change or agricultural practices (Cole et al., 2002; Barbaro and van Halder, 2009; Ozinga et al. 2009, Vandewalle et al., 2010). For example, Ozinga et al. (2009) showed that differences between plant species in characteristics (traits) involved in dispersal processes contribute significantly to explaining losses in plant 21 diversity in response to habitat degradation.

Species traits of diverse communities (plants, carabids, butterflies, birds, spiders) also have been shown to vary with environmental factors such as habitat fragmentation (Barbaro and van Halder, 2009), presence of planted hedgerows in highway verges (Le Viol et al., 2008), post-fire age (Langlands et al., 2011), salinity (Pavoine et al., 2011), agricultural land 
1 use and urbanisation (Vandewalle et al., 2010). Nevertheless, the role of habitat constraints

2 and dispersal abilities as filters, allowing only species with similar traits to assemble, has

3 never been demonstrated at broad spatial scales, due to lack of suitable data, especially in soil

4 invertebrates (Barbaro and van Halder, 2009; Decaëns et al., 2011; Makkonen et al., 2011;

5 Pavoine et al., 2011). This may bias to a great extent the relationships between habitat

6 preferences and species traits. Because the overall species response to habitat constraints

7 involves trade-offs (Uriarte et al., 2012) between responses to different environmental factors

8 (e.g. bedrock and climate, habitat openness and humidity, or temperature, or soil $\mathrm{pH}$ ), it is

9 easy to correlate erroneously a trait to an environmental factor. For example, the collembolan

10 species Heteromurus nitidus, thought to strictly depend on soil $\mathrm{pH}$ since it was never found in

11 soils at $\mathrm{pH}<5$ in North and West of France (Ponge, 1980, 1993), was later found in soils at

$12 \mathrm{pH}<4$ in south-western mountains of France (Cassagne et al., 2003, 2004). One way of avoiding this error risk is to determine habitat preferences of species over a wide range of habitats, encompassing a variety of temperature and altitude levels, at a scale close to the geographic distribution range of the species.

Moreover, despite the abundance, high diversity and essential functional role of soil invertebrates (Hopkin, 1997; Coleman et al., 2004), trait-based approaches were not explicitly used to study species/environment patterns and processes in these animal groups (Vandewalle et al 2010). Only studies focusing either on a restricted number of traits (especially dispersal), or of habitats have been made to assess the effects of land-use disturbance or climate change on soil communities (Ponge et al., 2006; Vandewalle et al., 2010; Decaëns et al., 2011; Makkonen et al., 2011; Bokhorst et al., 2012).

The taxonomic Class of Collembola is a good model to address such questions, because it comprises a high number of species, occupying highly diverse habitats over a broad biogeographic area (Hopkin, 1997). Moreover, some authors have hypothesized, from field 
1 observations, the existence of five or more "eco-morphological groups" based on conspicuous

2 morphological differences among Collembola living in diverse habitats (Gisin, 1943;

3 Delamare-Deboutteville, 1951; Rusek, 2007). They classified collembolan species according

4 to the relationships between some morphological characteristics and different gradients of 5 vertical stratification (edaphic, hemiedaphic, epigeic) and soil moisture (hydrophilic, 6 xerophilic), but no attempt was made to rely statistically morphological characteristics (traits) 7 to environmental variables. Europe, as a wide area including a high diversity of landscape 8 and vegetation types, is a favourable terrain for exploring multivariate relationship between 9 species trait values, assembly processes, and environmental factors.

10 In this study, we asked the following questions: (1) What is the pattern of relationships 11 between species assemblages and environmental variables at broad geographic scale?

12 Which environmental variables are associated with trait variation in Europe and which environmental variables contribute to the assemblage of local communities?

To this end, we compiled a large volume of data about species traits and environmental characteristics of sites where species have been collected throughout Europe. To enable this, we created 'Coltrait', a database collating traits and occurrence data of 17 European collembolan species across a wide range of habitats, mostly from Northwest Europe. Occurrence data and associated descriptions of samples and sampling sites were either provided by our own studies, or collected in the literature. For traits, we selected collembolan characteristics expected to explain the distribution of species and the subsequent composition of species communities through three processes that drive patterns of community composition, namely (1) Abiotic components of habitat, (i.e. environmental variables) adaptation/selection (e.g. sensorial organs, cuticle protection, reproduction type);

Dispersal ability (e.g. locomotory appendages); (3) Biotic components of habitat selection (predator defence, e.g. detection by sensory organs, excretion of repulsive substances). 
We firstly analyzed the impact of environmental variables on the distribution of species in

2 Europe, and then we analyzed patterns of trait/environment relationships.

3

\section{Materials and methods}

\subsection{Data collection}

2.1.1. Habitat characteristics and species occurrences

The Coltrait database comprises four tables that were used for the present study: a species traits table, a sample description table (environmental variables observed in samples or in sample sites to determine habitat characteristics), an occurrence/sample table and a bibliography table.

Habitat characteristics and occurrences of collembolan species in these habitats were provided either by our own studies (Arpin et al., 1984, 1985, 1986; Ponge, 1980, 1993; da Gama et al., 1994, 1997; Ponge, 2000; Loranger et al., 2001; Ponge et al., 2003; Gillet and Ponge, 2005) or were extracted from articles dealing with field studies on collembolan communities (e.g. Hågvar, 1982; Rusek, 1989, 1990; da Gama et al., 1994, 1997; Cassagne et al., 2003, 2004; Dunger et al., 2004; Chauvat et al., 2007; see Appendix 1 for the complete list of references). We selected habitat characteristics (environmental variables) that were described for a large amount of samples, proved to be linked to the composition of communities at local scale in previous studies and/or were susceptible to "filter" species traits.

We collected qualitative and quantitative data regarding site and sample descriptions (i.e. habitat characteristics) of 926 samples. Quantitative data (temperature and rainfall, altitude, soil $\mathrm{pH}$ and $\mathrm{C} / \mathrm{N}$ ) were directly incorporated in the data base (Table 1). We aggregated qualitative data into binary classes, assigning each sample to one of two classes 
1 for each modality of a given habitat: "1" if sampling occurred in the modality (e.g. close

2 habitat, mull humus...), "0" if sampling did not occur in the modality and this for each field

3 study. Modalities were (1) for habitat closure "close" (forest, wood), "open" (pasture,

4 grassland, meadow, cultivated field) and "intermediate" (hedgerow, forest clearing, forest

5 edge, heathland), (2) for soil characteristics "mull", "moder" and "mor" humus, "peat" and

6 "cultivated" soil, "organic" and "organo-mineral" horizons and "hydromorphic" soils, (3) for

7 vertical stratification "edaphic" (soil), "hemiedaphic" (litter), "epigeic-1" (ground surface and

8 mosses), "epigeic-2" (herb layer, boulder), "epigeic-3" (tree trunk and canopy) (Table 1).

These data allowed us determining the occurrence of species and their traits along several environmental gradients: vertical stratification, habitat closure, soil acidity, 11 decomposition rate (humus form and $\mathrm{C} / \mathrm{N}$ ), moisture, minimum annual air temperature 12 (hereafter named "temperature"), minimum annual rainfall (hereafter named "rainfall") and altitude.

As sampling strategies varied between different studies and was not always precisely described regarding every sampling area, volume or depth of soil, we only compiled the presence/absence of species and not their abundance. We selected species that were recorded in at least 10 studies and 20 samples, providing a list of 58 most frequent collembolan species in Europe (Table 2). Habitat and species occurrence data covered the following countries: Germany, United Kingdom, Austria, Belgium, Denmark, Spain, Finland, France, Italy, Norway, the Netherlands, Poland, Portugal, Czech Republic, Slovakia, Sweden, two thirds of 21 samples being from France. Available data from Greece were discarded because the 58 selected species were generally present in the 17 above-cited countries while 33 species out of 58 were not recorded in Greece according to Fauna Europaea. Consequently, in our analysis, biogeographic segregation does not bias species distribution. 


\subsubsection{Species traits}

We first listed traits that were most likely to influence community assembly either through habitat characteristics, dispersal abilities, or biotic interactions. We then eliminated traits for which detailed and complete information was not available for a high number of species. This selection step provided a set of 11 morphological traits and one life-history trait (reproduction mode). Physiological traits would have been highly relevant, however, as far as we are aware this information is only available for a few species reared in laboratory conditions. In the same way, life-history traits were poorly informed except for reproduction mode.

Traits were collected from a number of specified synopses and identification keys (Gisin, 1960; Jordana et al., 1997; Fjellberg, 1998, 2007; Bretfeld, 1999; Potapow, 2001; Thibaud et al., 2004; Chahartaghi et al., 2006; Hopkin, 2007; Chernova et al., 2009; Dunger and Schlitt, 2011). Visual and jumping apparatus and leg lengths are supposed to be related to dispersal abilities of species (Ponge et al., 2006). Antennal length, eye (ocelli) number, presence of trichobothria and presence and complexity of post-antennal organs play a role in sensory functions (Hopkin, 1997) and are expected to vary between close versus open, and epigeic versus endogeic habitats. Body pigmentation and presence of scales are involved in UV protection, thermodynamic buffering and signalling (Hopkin, 1997) and are also suspected to vary with habitat characteristics, as well as body shape and length and length of jumping apparatus. Pseudocelli are circular structures allowing Collembola to extrude repulsive fluids from specialized glands (Hopkin, 1997; Rusek and Weyda, 1981) and thus play a role in protection against predation (Rusek and Weyda, 1981). At last sexual/parthenogenetic reproduction is associated to survival or colonizing strategy (Chernova et al., 2009; Lavelle et al., 1987). Most of these traits are species- or clade- (e.g. pseudocelli) specific and we did not consider here intra-specific variability since data on 
1 morphometric variation over broad geographical areas are unavailable in Collembola. Data

2 may be quantitative (e.g. body length), binary (e.g. presence/absence of scales), or semi-

3 quantitative (e.g. furcula length, see Table 3). We computed traits of the 58 selected

4 collembolan species. All trait attributes (e.g. furcula length categories) were issued from

5 precise definitions (Table 3) and not from expert appreciations. Some of these traits, currently

6 in the Coltrait database, will be integrated in the BETSI database (Hedde et al., 2012).

\subsection{Statistical analyses}

Correspondence analysis (CA) was used to analyze species-environment relationships without constraining species distribution (samples as observations, species as active variables, environmental variables as passive variables). As an explanatory step, CA allowed us to visualize patterns of species distribution with environmental variables superposed on the revealed gradients.

Canonical correspondence analysis (CCA) and Monte Carlo permutation tests were used to verify whether species distribution was significantly explained by environmental factors and to know the importance of each factor. The type of horizon (organo-mineral or organic) and the $\mathrm{C} / \mathrm{N}$ ratio were discarded because they were not available for a high number of samples. As Spearman correlation tests revealed that some environmental variables or levels of environmental variables were correlated we discarded some of them and we tested only the effect of temperature and rainfall (for climate), soil $\mathrm{pH}$, hydromorphy and only some modalities of habitat closure (Open), vertical stratification (Hemi, Epi-1, Epi-2,Epi-3), and humus forms (Mull, Moder). Missing values were estimated by the nearest neighbor method. Seven partial CCAs were then performed to test the effect of above-mentioned variables while discarding the effect of one of them on species distribution.

RLQ analyses (Dolédec et al., 1996) were performed to assess whether species traits distribution was significantly correlated with environmental variables, and to determine 
1 patterns observed when variables were constrained. RLQ analysis allows to perform a double

2 inertia analysis of two arrays (R: environmental variables, and Q: species traits) with a link

3 expressed by a contingency table (L: species occurrences). We discarded $\mathrm{C} / \mathrm{N}$, organo-mineral

4 and organic horizons and soil $\mathrm{pH}$, that were not sufficiently informed. As missing

5 observations were deleted when variables (e.g. mull, moder) were not fully informed (Table

6 1), and as informed variables varied among studies (either humus form, or climate) we

7 performed two RLQs to minimize the loss of data in each analysis. We transformed

8 quantitative data (temperature, altitude and rainfall, leg and furcula lengths, ocelli and PAO

9 vesicle numbers) into semi-quantitative data with three or two classes each. This

10 transformation was performed by discretizing data over two classes when the trait might be

11 absent and consequently it comprises a class "0" (e.g. ocelli, PAO vesicle numbers) in

12 addition to the two classes created by the discretization. Discretization was performed over three classes for the other traits (e.g. lengths). To limit deleting observations we pulled together samples taken either in edaphic or in hemiedaphic levels (S.Soil), creating a vertical stratification category gathering samples taken either from the soil or from the litter. We also created another level of vertical stratification (S.Soil-Epi) that includes moss cushions or grass tufts with adhering humus or soil. Other variables were the same as those used in CA (Table 3). The first RLQ tested the interaction of traits with climate, vertical stratification, habitat closure, and soil moisture, while the second RLQ tested the interaction of traits with humus form, habitat closure, and soil moisture.

At last, traits were analyzed separately using statistical models to test the effect of environmental variables highlighted by RLQ. We first calculated the percent occurrence of each species for each level of binary environmental variables (e.g. edaphic level, hemidaphic level, mull humus, moder humus, etc...), and for continuous environmental variables (soil $\mathrm{pH}$, altitude, temperature and rainfall) we selected minimum or maximum values for each 
1 species. We then implemented linear models on continuous trait values, binary logit models

2 on binary traits, and a multinomial logit model on pigmentation which included three

3 categories. We excluded variables with a variance inflation factor (VIF) higher than four to

4 avoid multi-colinearity. We selected models with contributive variables that significantly

5 explained the greatest part of trait variability (i.e. with highest adjusted $\mathrm{R}^{2}$ and log-likelihood

6 for linear and logit models, respectively). All variables bringing significant information to the

7 model were included, even if their impact was not significant when evaluated separately

8 (Type III analysis). In order to fulfill linear model assumptions, some variables had to be log-

9 transformed. As pseudocelli number did not follow a normal distribution even after transformation, we analyzed their presence/absence with a binary logit model.

11

RLQ analysis was performed with the package "ade4" in R software (R Development Core Team, 2010). CA, CCA, general linear models (GLM) and other calculations (e.g. data normalization, discretization) were done using $\operatorname{XLSTAT}^{\circledR}$ (Addinsoft $^{\circledR}$, Paris, France).

\section{Results}

\subsection{Species and environmental variables}

The relationship between species, environmental variables and traits was first analyzed by CA using samples as observations, species as active variables and environmental variables as passive variables (Figs. 1a, 1b). The first three components of CA extracted $17.4 \%$ of the total variance $(6.3 \%, 5.9 \%$ and $5.2 \%$ for $\mathrm{F} 1, \mathrm{~F} 2$ and $\mathrm{F} 3$, respectively). The projection of species and environmental variables along axes 1 and 2 (Fig. 1a) shows that species are spread along axis 1 mainly according to humus form, soil hydromorphy and habitat opening/closure and to a lesser extent soil acidity, temperature and altitude. Along axis 2, species are distributed according to vertical stratification, and to a lesser extent habitat closure/opening, soil hydromorphy, organic matter, and temperature. In the upper left side of the biplot, we find 
1 edaphic and hemiedaphic species living in acid soils with a low rate of organic matter

2 decomposition (peat, mor, moder): Micraphorura absoloni, Mesaphorura tenuisensillata,

3 Willemia denisi, Willemia anophthalma, Mesaphorura yosii, Micranurida pygmaea, Folsomia

4 quadrioculata, Protaphorura armata and Pogonognathellus flavescens. Opposed to this

5 group along axis 1, we find edaphic and hemiedaphic species living in mull on calcareous or

6 neutroacidocline soils: Stenaphorura denisi, Mesaphorura hylophila, Mesaphorura

7 krausbaueri, Heteromurus nitidus, Mesaphorura italica, Paratullbergia callipygos, and

$8 \quad$ Pseudosinella alba.

Opposed along axis 2 to these two groups of edaphic and hemi-edaphic species, we find epigeic species living on the soil surface (epigeic-1), herb layers and boulders (epigeic-2) and trees (epigeic-3) (Figs 1a, 1b): Orchesella cincta, Heteromurus major, Xenylla tullbergi Lepidocyrtus curvicollis, Xenylla grisea, Brachystomella parvula, Isotomurus palustris, Sminthurinus elegans, Sminthurides schoetti, Entomobrya multifasciata and Tomocerus minor. Species distribution according to soil characteristics (humus form, acidity) thus occurs mainly for endogeic and hemiedaphic species.

Epigeic species are separated along axis 1 by low temperature levels and hydromorphy gradients, O. cincta, H. major, X. tullbergi, X. grisea and L. curvicollis occurring more often in slightly drier and/or warmer habitats (Temp), while B. parvula, S. elegans, E. multifasciata, I. palustris and L. cyaneus prefer hydromorphic soils (Hydro). Forests (close) and open habitats are better separated by axis 3 (Fig. 1b) that opposes epigeic species living 21 preferentially in herb layers or exceptionally on boulders (epigeic-2) in open habitats $(S$. 22 elegans, B. parvula, L. cyaneus, E. multifasciata, S. schoetti, I. palustris), to epigeic species 23 living either at the soil surface (epigeic-1) or on trees (epigeic-3) in forests (X. tullbergi, $O$. 24 cincta, L. curvicollis, Entomobrya nivalis, X. grisea, Allacma fusca). Species segregation according to habitat closure thus mainly occurs for epigeic species. Parisotoma notabilis 
1 shows no preferences for the studied factors, like the very common species Isotomiella minor,

2 which tends nevertheless to be observed more frequently in non-acidic soils.

CCA indicated that the bulk of tested environmental variables, i.e. humus form, habitat closure, vertical stratification, hydromorphy, temperature, rainfall and soil $\mathrm{pH}$ significantly impacted species distribution (Table 4). The seven partial CCAs computed without either vertical stratification (Hemie, Eda, Epi1, Epi2, Epi3), or humus form (Mull, Moder), or habitat closure (Open), or hydromorphy, or rainfall, or temperature, or soil $\mathrm{pH}$ showed that remaining factors impacted significantly the distribution of species (all $\mathrm{p}<0.0001$ ) but with a decrease in the rate of constraint inertia. This indicates that all factors impacted the distribution of species directly and not only through interactions with other factors. However, 11 discarding the effect of one or the other variable did not affect to the same extent the constrained inertia $(12.5 \%$ for total CCA): $5.2 \%, 8.0 \%, 10.5 \%, 10.6 \%, 10.6 \%, 11.5 \%$, and $11.6 \%$ of the total inertia were explained when discarding vertical stratification, humus form, rainfall, temperature, habitat closure, hydromorphy and $\mathrm{pH}$ effect, respectively.

\subsection{Traits and environmental variables}

A first RLQ analysis was applied to climate (temperature and rainfall), altitude, vertical stratification, habitat closure, soil moisture, and traits (Figs. 2a, 2b). Axis 1 separates levels of rainfall, temperature, vertical stratification, soil hydromorphy, and to a lesser extent, altitude. Axis 2 separates modalities of the same factors than for axis 1 in addition to habitat opening/closure. Traits mostly represented in deep soil and closed habitats (on the positive side of axes 1 and 2) are the absence of pigmentation, furcula, ocelli, trichobothria and scales, the presence of a post-antennal organ (PAO) comprising a great number of vesicles, of pseudocelli (defense organs), short legs and antennae and small body length. These habitats also display a parthenogenetic dominant reproduction. On the soil surface, the 
number of ocelli and furcula length increased slightly. When habitats are less edaphic, more open and in less favorable climatic conditions (higher altitude, associated to low temperature levels positive side of axis 1 and negative side of axis 2) the following trait modalities are more frequent: stocky body, variable pigmentation, PAO present but less developed, and furcula, present but usually regressed and not fully functional. In epigeic habitats and more favorable climatic conditions (i.e. high and intermediate temperature levels and lower altitude, negative side of axis 1) most common traits are larger body size, elongated legs and antennas, spherical and pigmented body, well-developed eyes, presence of trichobothria and scales, and absence of PAO and pseudocella, with sexual reproduction dominant.

A second RLQ tested the relationships between humus forms and soil types, habitat closure, soil moisture, and traits (Figs. 3a, 3b). Axis 1 separates closed and open habitats while axis 2 separates humus forms. Open habitats (positive side of axis 1) hosted species displaying traits previously mostly observed in epigeic and favorable climate conditions: increased body, leg and antennae length, spherical and pigmented body, with scales and trichobothria, well-developed eye spots, absence of pseudocelli, absence or reduction of PAO vesicles, and dominance of sexual reproduction. Furcula may be either very long or regressed. Near the positive end of axis 1, higher body length is found in well moistened soils. Closed (forest) and intermediate (heathland and scrub) habitats (negative side of axis 1) are separated along axis 2 according to humus form and thickness of organic horizon. Small body, leg and antennae length, with pseudocella and well developed PAO, but no pigmentation, scales and trichobothria, are observed in both mull and moder humus (negative side of axis1 and axis 2). Some traits varied along axis 2 in relation to the humus form, especially the increase in organic horizon thickness. From mull to moder the following changes are observed: mixed reproduction shifts towards parthenogenesis, absence of eye towards simple eye, absence of furcula towards mean-length furcula. In humus forms with 
thickest organic layers (Mor and Peat) particular traits are observed, e.g. stocky body, short furcula and variable pigmentation. This change of traits from mull with thin organic layers to humus forms with thicker organic layers (moder, then mor and peat) coincides with the passage from deep organo-mineral horizons with small interconnected pores (earthworm galleries, allowing Collembola to go deeper in the soil as in mull) to upper thick organic horizons that offer more space, allowing the movement of large bodies and the use of a medium-size or short furcula, while eyes are larger in relation to a little more light.

Monte-Carlo tests based on 1000 replicates were highly significant $(\mathrm{p}<0.001)$ for the two RLQs, indicating a significant relationship between traits and environmental variables.

Linear and logistic models showed that environmental variables explained antenna,

2 leg, body and furcula lengths, number of eyes and PAO vesicles, reproduction mode, 3 spherical and cylindrical body shape, and presence of trichobothria, pseudocelli, scales and 4 pigment to significant levels (Tables 5 and 6). Only the stocky body shape (McFadden $\mathrm{R}^{2}=$ $5 \quad 0.099 ; \mathrm{Chi}^{2}=3.362 ; \mathrm{p}$-value $\left.=0.067\right)$ was not significantly explained by environmental 6 variables. Logistic and linear regressions corroborated that temperature plays a significant 7 part in the explanation of most trait variation (Tables 5 and 6). Antenna, furcula, leg, and 8 body lengths, number of ocelli, sexual reproduction, spherical body shape, and presence of 9 trichobothria were significantly and positively explained by minimum temperatures. Some of 10 these traits tended to be (body length) or were (trichobothria) negatively explained by altitude. 11 Vertical stratification (mostly through epigeic and hemiedaphic levels) contributed to the 12 explanation of all traits (except stocky body). Both the number of PAO vesicles and the 13 presence of pseudocelli were significantly and negatively explained by minimum 14 temperatures and epigeic-1 level, and were positively explained by soil $\mathrm{pH}$. Humus form and 
1 habitat openness contributed to explain variations of only five and two traits, respectively, and

2 this contribution was significant in two cases only (peat and mor explained trichobothria 3 presence and antenna length, respectively).

\section{Discussion}

\subsection{Species and environmental variables}

9 We showed that the distribution of species is conditioned, first by vertical stratification, then by humus form, air temperature, rainfall, and habitat closure. Soil moisture and acidity were also shown to affect species distribution but more indirectly, probably through the effect of humus form (Ponge et al., 2002; Cassagne et al., 2004), while the effect of altitude was correlated to air temperature and rainfall (and more probably to insolation). These results arise from an analysis performed at a broad scale, that covers most part of the biogeographic distribution area of species. The multiplicity of sites over such a broad geographical scale allows to overcome eventual interactions between spatial autocorrelation and environmental variables that could arise at lower scales, e.g. at the scale of habitat (e.g. a forest) or microhabitat (e.g. soil characteristics) (Caruso et al., 2012).

Our results show that these habitat constraints contributed in structuring collembolan communities to an extent of about $12 \%$. Consequently, at least $12 \%$ collembolan species assemblies were explained in a deterministic way (Streit et al., 1985; Weiher and Keddy, 1995) while about $88 \%$ species distribution remained unexplained. A part of this unexplained variation is probably due to the lack of data about biotic interactions like competition (McGill et al., 2006; Comita et al., 2009). 
We characterized habitat preferences for many species (see section 3.1.). The three

2 levels of epigeic species were well separated between soil surface (epige-1), herb layers and

3 boulders (epige-2) and trees (epige-3) while hemiedaphic species were closely related to

4 edaphic species. This could in part be due to the fact that some samples contained a mixture

5 of litter and organo-mineral or even mineral soil (soil), leading to a connection of species

6 living in one or the other level, but also to the vertical movement of animals through horizons

7 (Hassall et al., 1986). The distribution of species in the three epigeic levels was related to 8 habitat closure, above-ground species that live in forests being preferentially located either at

9 the soil surface (epige-1) or on trees (epige-3), contrary to above-ground species living in open areas which are located preferentially in herb layers or on boulders (epige-2). Species segregation according to habitat closure thus especially occurs for epigeic species because they are living far from the protection ensured by soil/litter layers, and occupy different substrata, some of them being more frequent in forests (trees) or in open environments (herb layers). Edaphic species appear in both closed and open habitats while hemiedaphic species seem more linked to closed habitats (due to thicker litter layers). However, their central location on the F2-F3 biplot of CA makes hemiedaphic habitats more difficult to interpret in terms of relationships with habitat closure. Edaphic species were actually segregated according to humus form and acidity.

Our results support studies done at a more local scale on the vertical distribution of species (Delamare-Deboutteville, 1951; Hale, 1966; Hågvar, 1983; Ponge, 2000), preferences

21 for humus forms and soil acidity levels (Ponge, 1983; Hågvar and Abrahamsen, 1984; 22 Loranger et al., 2001), and comparisons between forests and open habitats (Ponge, 1993). They reveal an impact of the minimum annual air temperature at which species have been found as well as the segregation of epigeic species among the three levels of epigeic habitats (see above). However, as our analysis encompasses a broad spatial area, and consequently 
1 more diverse levels of environmental factors, we found some contrasted results compared to

2 more local studies. For example Mesaphorura macrochaeta, previously observed in more

3 relative abundance in acidic soils in a more local study (Ponge, 1993), is here found not really

4 responding to acidity level, and even tending to occur more often in subacidic or non-acidic

5 soils. The collembolan $H$. nitidus, proved to prefer edaphic and hemiedaphic habitats in mull

6 humus and calcareous or neutroacidocline soils (see 2.2 Results) on a broad scale, was able to

7 live in acidic soil in some places (Cassagne et al., 2003, 2004). Such contrasted responses of species to varied environmental conditions show that the response (reaction norm) of species results from trade-offs between preferences for a variety of environmental factors and varies according to the value of each factor (Fry, 2003; Uriarte et al., 2012). They also highlight that in spite of marked habitat preferences, the studied collembolan species were able to live in extremely diverse conditions. Consequently, the niche width will remain to be defined for the present 58 species in order to determine precisely the habitat limits of each species and thus provide a tool that could be used for eventual predictions of changes in collembolan communities. Nevertheless, we have to keep in mind that some species appearing in our study as ubiquitous, such as Parisotoma notabilis or Isotomiella minor, might in fact be species complexes composed of two or more species with narrower niches as suggested by recent sequencing of a barcode DNA fragment (5' end of COI gene) (Porco et al, 2012).

\subsection{Traits and environmental variables}

RLQ and GLM analyses showed that all tested environmental variables contributed to the assemblage of species traits. Vertical stratification followed by annual air temperature play a dominant role in the explanation of variation of the 12 studied traits.

The relationship between traits and vertical distribution of species, which was previously hypothesized by Collembola specialists (Gisin, 1943; Delamare-Deboutteville, 
1 1951; Hågvar, 1983; Rusek, 2007) on the basis of their observations, is now statistically

2 tested over a wide range of ecosystems. The contribution of habitat closure/openness and

3 humus form to traits assemblages is showed at broad scale for the first time. We also showed

4 that traits of species living in open habitats (e.g. grassland) or above-ground are both adapted

5 to surface life, i.e. to light, a potentially dry environment and a wide space: high mobility

6 (long legs and furcula), big size often associated with spherical body, scales, pigments

7 (protection against UV), sensorial organs sensitive to air and light (trichobothria, ocelli and antennal organs), and sexual reproduction. On the opposite side, traits that are dominant in woodland are quite similar to those observed in hemiedaphic and edaphic levels and are mostly associated with subterranean concealed life or at least with a stable microclimate (litter in forests): small size, small locomotory appendices, toxic excreta (pseudocelli), post-antennal organs as main sensorial organs, and parthenogenesis. Such variation of trait modalities between open habitats and forests probably explain the higher soil fauna diversity $(\gamma-$ diversity) observed in landscapes composed of a mixture of forests and open habitats in regard to homogeneous landscapes (Vanbergen et al, 2007).

The convergence of traits observed along gradients of habitat closure and of vertical distribution is explained by a higher incidence of environmental stress (drought, UV and wind) in less protected open as well as aboveground habitats. Among species previously recorded as drought-sensitive (Lindberg and Bengtsson, 2005), many appears here as being edaphic and woodland species (Micraphorura absoloni, Willemia anophthalma, Micranurida pygmaea, Mesaphorura macrochaeta), while drought-tolerant species are found to be epigeic (Lepidocyrtus spp., Entomobrya nivalis).

The relatively large body size of epigeic species is a protection strategy against frost and desiccation (Kaersgaard et al., 2004, Bokhorst et al., 2012). Moreover, open unstable and stressful environments like agricultural fields require higher motility (long legs and furcula) 
1 than shrubby fallows where litter begins to accumulate or woodland (Mebes and Filser, 1997).

2 Escaping from predators aboveground also relies on jumping, ensured by long furcula acting as a spring (Bauer, 1987), as well as visual (ocelli) or tactile (trichobothria) sensorial organs to detect their presence (Baatrup et al., 2006). In epigeic and open habitats longer antennae, bearing specialized tactile and chemosensory setae and vesicles, also allow detecting 6 chemicals and air vibration at a higher distance (Hopkin, 1997). Increased ocelli number and 7 furcula, antenna and body lengths were also used by Rusek (2007) to propose two epigeic collembolan "life form groups", namely "Macrophytobionts" and "Microphytobionts", corresponding to epigeic levels 2 and 3, respectively, in our study. Conversely, reduced pigmentation, furcula length and number of ocelli fit generally well with the "Euedaphobiont life form group" (Rusek, 2007). Ocelli number, antenna and furcula lengths had also previously been shown to be correlated with change in the vertical distribution of species in response to tree plantation affecting litter quality and quantity (Vandewalle et al., 2010).

Pseudocelli, mostly present in edaphic species, probably compensate for the difficulty to escape predators through active movement in deep soil by excreting chemicals that repel predators (Negri, 2004). In the same way the presence of post-antennal organs (PAO) in edaphic and hemiedaphic species only, support the hypothesis raised by Salmon and Ponge (2012) that these organs could compensate for the absence of other sensorial organs that are adapted to air (trichobothria), light (ocelli) and spacious environments (sensory organs on long antennae), PAO being supposed to be composed of thermo-, hygro-, or chemosensitive receptor cells (Altner, 1976). At last, the reproductive insurance hypothesis (Jain, 1976) predicts that parthenogenesis is favored in populations where mates are difficult to find. This hypothesis can explain the higher rate of parthenogenesis observed among euedaphic species, living in deep soil horizons and faced to deficit of space and need to explore narrow soil pore networks for mating (Chahartaghi et al., 2006; Chernova et al., 2009). 
The effect of climate, and especially of temperature, on the distribution of traits is

2 mostly observed in aboveground and open habitats, i.e. in least protected and more unstable environments. Moreover, as climate drives vegetation patterns and humus forms (Ponge et al, 2011), the effect of climate seems tightly linked to that of humus forms. In this way, less favorable climatic conditions (high altitude associated with low temperature levels), when they allow vegetation development, often generate mor humus and peat, i.e. humus with thick organic horizons made of undecayed plant fragments where collembolan species with stocky body can move more easily than in small soil pores, and are impeded to go deep in the soil by waterlogging. Such conditions favor traits that are intermediate between strictly edaphic and epigeic life (pigmentation variable, PAO present but less developed, and short or regressed furcula). Species traits observed under more favorable climate conditions (moderately high temperature and moisture and low altitude), are the same as those present in epigeic levels because such conditions are favorable to epigeic life and because species adapted to drought can live above-ground in open habitats (see above; Siepel, 1996). This is supported by the positive correlation of the activity of epigeic Collembola with temperature in agricultural soils (Frampton et al., 2001). At last, the postantennal organ seems more complex (larger numbers of vesicles, in relation to the number of dendritic branches of neural systems; Altner and Thies, 1976) in most species of mull humus and edaphic levels than in moder humus and hemiedaphic levels. This suggests that complex post-antennal organs, supposed to be more sensitive to chemical features of the immediate environment (Altner and Thies, 1976), could compensate for the complete absence of eyes and reduction of other sensory organs observed in euedaphic species, providing better adaptation to deeper soil layers. Nevertheless, although the presence of PAO was essentially 
1 complexity in relation to habitat depth of each species along one or several lineages will be

2 able to state on the importance of PAO complexity for adaptation to subterranean life. observed in a previous study realized at a more local scale (Salmon and Ponge, 2012). Nevertheless, some differences have to be noted since the cited study did not allow discerning a clear correlation between traits and humus types associated to soil acidity. The larger dataset used here allowed us to demonstrate such relationships. The present study, by showing the change of traits along environmental gradients supports the importance of niche-based environmental filtering in the assembly of Collembolan species (McGill et al., 2006, Weiher et al, 2011). However, models showed that environmental variables explained $23 \%$ (cylindrical body) to $71 \%$ (pseudocelli; Table 6) of trait variation, meaning that a high part of trait and species assembly variation is explained by other factors. Community phylogenetics will probably add an important contribution to the explanation of species distribution and assembly as this has been shown for plant communities (Prinzing et al., 2008; Pavoine et al., 2011). In addition, ecophysiological traits such as resistance to desiccation, enzymatic equipment for food digestion, colonization rate, etc., were missing in our analysis because they were only available for a few species (Hopkin, 1997) and lengthy researches are needed to assess them in a meaningful number of species. At last, although pseudocelli and furcula development allow taking into account repulsion to and escape from predators, respectively, the effects of other biotic interactions such as competition, or commensalism, known to be important drivers of community structuration (McGill et al., 2006; Comita et al., 2009; Vellend, 2010), were not taken into account because of the little amount of available data. Limits of models relating species range distributions to environmental variables have been underlined, in particular when using species- or traitenvironment relationships to track large-scale effects of global change (Fridley and Wright, 
1 2012; Urban et al., 2013; Zhu et al., 2014). We showed that within the studied group climate

2 effects concern mainly traits associated to aboveground habitats in open environments, and

3 that soil properties are the main driver of changes in belowground communities. However,

4 predictions about the response of collembolan trait/species distributions at local scale to

5 climate warming will have to take into account other factors like biotic interactions (Urban et

$6 \quad$ al., 2013) and ecophysiological traits.

7

8

9

\section{Conclusions}

Our study shows that collembolan species assembly at a broad scale is conditioned by a set of interacting parameters including vertical stratification, humus form, habitat closure, air temperature, soil moisture and acidity, and to a lesser extent rainfall and altitude. Our results show that all these environmental factors significantly contributed to the assemblages of twelve studied species traits. Combinations of certain environmental factors, especially stratification level and air temperature, explain a large variety of species traits and are thereby thought responsible for a great part of collembolan "species sorting". A convergence was observed between traits related to stratification level and habitat closure/openness, that we interpreted as the effect of similar physiological and behavioral constraints. The action of humus form would impact indirectly trait distribution/assembly through the interaction between vertical stratification and habitat openness. Ecological preferences were identified for the 58 studied collembolan species relatively to this set of traits, their niche width and their degree of specialization remaining to be more precisely defined. Nevertheless, relationships between traits and environments provide interesting proxies to identify ecological preferences 
1 of Collembola, even when not identified to species level. Beyond Europe (where the invertebrate fauna is relatively well-characterized), this approach may offer new insight, for example with respect to tropical soil communities where most species are still unknown to science, and will likely remain so in the near future.

Altner, H., Thies, G., 1976. The postantennal organ: a specialized unicellular sensory input to the protocerebrum in apterygotan insects (Collembola). Cell and Tissue Research 167, 97110.

Arpin, P., David, J.F., Guittonneau, G.G., Kilbertus, G., Ponge, J.F., Vannier, G., 1986. Influence du peuplement forestier sur la faune et la microflore du sol et des humus. Revue d'Écologie et de Biologie du Sol 23, 119-153.

Arpin, P., Kilbertus, G., Ponge, J.F., Vannier, G., Verdier, B., 1985. Réactions des populations animales et microbiennes du sol à la privation des apports annuels de litière : exemple d'une rendzine forestière. Bulletin d'Écologie 16, 95-115.

Arpin, P., Ponge, J.F., Dabin, B., Mori, A., 1984. Utilisation des nématodes Mononchida et des collemboles pour caractériser des phénomènes pédobiologiques. Revue d'Écologie et de Biologie du Sol 21, 243-268.

Baatrup, E., Bayley, M., Axelsen, J.A., 2006. Predation of the mite Hypoaspis aculeifer on the springtail Folsomia fimetaria and the influence of sex, size, starvation, and poisoning. Entomologia Experimentalis et Applicata 118, 61-70.

Barbaro, L., van Halder, I., 2009. Linking bird, carabid beetle and butterfly life-history traits to habitat fragmentation in mosaic landscapes. Ecography 32, 321-333.

Bauer, T., Christian, E., 1987. Habitat dependent differences in the flight behavior of Collembola. Pedobiologia 30, 233-239.

Belyea, L.R., Lancaster, J., 1999. Assembly rules within a contingent ecology. Oikos 86, 402416.

Bokhorst, S., Phoenix, G.K., Bjerke, J.W., Callaghan, T.V., Huyer-Brugman, F., Berg, M.P., 2012. Extreme winter warming events more negatively impact small rather than large soil fauna: shift in community composition explained by traits not taxa. Global Change Biology $18,1152-1162$.

Bretfeld, G., 1999. Synopses on Palaearctic Collembola. Volume 2. Symphypleona. Abhandlungen und Berichte des Naturkundemuseums Goerlitz 71, 1-318. 
Caruso, T., Taormina, M., Migliorini, M., 2012. Relative role of deterministic and stochastic determinants of soil animal community: a spatially explicit analysis of oribatid mites. Journal of Animal Ecology 81, 214-221.

Cassagne, N., Bal-Serin, M.C., Gers, C., Gauquelin, T., 2004. Changes in humus properties and collembolan communities following the replanting of beech forests with spruce.

6 Pedobiologia 48, 267-276.

Cassagne, N., Gers, C., Gauquelin, T., 2003. Relationships between Collembola, soil chemistry and humus types in forest stands (France). Biology and Fertility of Soils 37, 355361.

Chahartaghi, M., Scheu, S., Ruess, L., 2006. Sex ratio and mode of reproduction in Collembola of an oak-beech forest. Pedobiologia 50, 331-340.

Chauvat, M., Wolters, V., Dauber, J., 2007. Response of collembolan communities to landuse change and grassland succession. Ecography 30, 183-192.

Chernova, N.M., Potapov, M.B., Savenkova, Y.Y., Bokova, A.I., 2009. Ecological significance of parthenogenesis in collembola. Zoologichesky Zhurnal 88, 1455-1470.

Cole, L.J., McCracken, D.I., Dennis, P., Downie, I.S., Griffin, A.L., Foster, G.N., Murphy, K.J., Waterhouse, T., 2002. Relationships between agricultural management and ecological groups of ground beetles (Coleoptera: Carabidae) on Scottish farmland. Agriculture, Ecosystems and Environment 93, 323-336.

Coleman, D.C., Crossley, D.A.J., Hendrix, P.F., 2004. Fundamentals of Soil Ecology. Academic Press, Amsterdam.

Comita, L.S., Uriarte, M., Thompson, J., Jonckheere, I., Canham, C.D., Zimmerman, J.K., 2009. Abiotic and biotic drivers of seedling survival in a hurricane-impacted tropical forest. Journal of Ecology 97, 1346-1359.

da Gama, M.M., Sousa, J.P., Ferreira, C., Barrocas, H., 1997. Endemic and rare Collembola distribution in high endemism areas of south Portugal: a case study. European Journal of Soil Biology 33, 129-140.

da Gama, M.M., Sousa, J.P., Vasconcelos, T.M., 1994. Comparison of Collembolan populations from Portugese forests of Quercus rotundifolia Lam. and Eucalyptus globulus Labill., In: Almaça, C. (Ed.), Professor Germano da Fonseca Sacarrão (1914-1992). Museu Nacional de História Natural, Museo Bocage, Lisboa, Portugal, pp. 201-214.

Decaëns, T., Margerie, P., Renault, J., Bureau, F., Aubert, M., Hedde, M., 2011. Niche overlap and species assemblage dynamics in an ageing pasture gradient in north-western France. Acta Oecologica 37, 212-219.

Delamare-Deboutteville, C., 1951. Microfaune du sol des pays tempérés et tropicaux. Hermann, Paris, France.

Devictor, V., Clavel, J., Julliard, R., Lavergne, S., Mouillot, D., Thuiller, W., Venail, P., 38 Villeger, S., Mouquet, N., 2010. Defining and measuring ecological specialization. Journal of 39 Applied Ecology 47, 15-25. 
Dolédec, S., Chessel, D., ter Braak, C.J.F., Champely, S., 1996. Matching species traits to environmental variables: a new three-table ordination method. Environmental and Ecological Statistics 3, 143-166.

Dunger, W., Schlitt, B., 2011. Synopses on Palaearctic Collembola: Tullbergiidae. Soil 5 Organisms 83, 1-168.

Dunger, W., Schutz, F.J., Zimdars, B., Hohberg, K., 2004. Changes in collembolan species composition in Eastern German mine sites over fifty years of primary succession.

8 Pedobiologia 48, 503-517.

9 Fjellberg, A., 1998. The Collembola of Fennoscandia and Denmark. Part 1: Poduromorpha. 10 Fauna Entomologica Scandinavica 35, 1-183.

11 Fjellberg, A., 2007. The Collembola of Fennoscandia and Denmark. Part II: 12 Entomobryomorpha and Symphypleona. Fauna Entomologica Scandinavica 42, 1-264.

Frampton, G.K., van den Brink, P.J., Wratten, S.D., 2001. Diel activity patterns in an arable collembolan community. Applied Soil Ecology 17, 63-80.

Fridley, J.D., Wright, J.P., 2012. Drivers of secondary succession rates across temperate latitudes of the eastern USA: climate, soils, and species pools. Oecologia 168, 1069-1077.

Fry, J.D., 2003. Detecting ecological trade-offs using selection experiments. Ecology 84, $18 \quad 1672-1678$.

Gillet, S., Ponge, J.F., 2005. Species assemblages and diets of Collembola in the organic matter accumulated over an old tar deposit. European Journal of Soil Biology 41, 39-44.

Gisin, H., 1943. Ökologie und Lebensgemeinschaften der Collembolen im schweizerischen Exkursionsgebiet Basels. Revue Suisse de Zoologie 50, 131-224.

Gisin, H., 1960. Collembolenfauna Europas. Muséum d'Histoire Narurelle, Genève, Switzerland.

Hågvar, S., 1982. Collembola in Norwegian coniferous forest soils. I. Relations to plant communities and soil fertility. Pedobiologia 24, 255-296.

Hågvar, S., 1983. Collembola in Norwegian coniferous forest soils. II. Vertical distribution. Pedobiologia 25, 383-401.

Hågvar, S., Abrahamsen, G., 1984. Collembola in Norwegian coniferous forest soils. III. Relations to soil chemistry. Pedobiologia 27, 331-339.

Hale, W.G., 1966. A population study of moorland collembola. Pedobiologia 6, 65-99. 
complete framework for studying soil invertebrate functional traits. In: XVI ICSZ International Colloquium on Soil Zoology, Coimbra, Portugal.

Hopkin, S.P., 1997. Biology of the Springtails (Insecta: Collembola). Oxford University

4 Press, Oxford, UK.

Hopkin, S.P., 2007. A key to the Collembola (springtails) of Britain and Ireland. Field Studies

6 Council, Shrewsbury, UK .

Jain, S.K., 1976. The evolution of inbreeding in plants. Annual Review of Ecology and Systematics 7, 469-495.

Jordana, R., Arbea, J.I., Simon, C., Lucianez, M.J., 1997. Fauna Iberica. Collembola, Poduromorpha. Museo Nacional de Ciencias Naturales, Madrid, Spain.

Kaersgaard, C.W., Holmstrup, M., Malte, H., Bayley, M., 2004. The importance of cuticular permeability, osmolyte production and body size for the desiccation resistance of nine species of Collembola. Journal of Insect Physiology 50, 5-15.

Langlands, P.R., Brennan, K.E.C., Framenau, V.W., Main, B.Y., 2011. Predicting the postfire responses of animal assemblages: testing a trait-based approach using spiders. Journal of Animal Ecology 80, 558-568.

Lavelle, P., Barois, I., Cruz, I., Fragoso, C., Hernandez, A., Pineda, A., Rangel, P., 1987. Adaptive strategies of Pontoscolex corethrurus (Glossoscolecidae, Oligochaeta), a peregrine geophagous earthworm of the humid tropics. Biology and Fertility of Soils 5, 188-194.

Le Viol, I., Julliard, R., Kerbiriou, C., de Redon, L., Carnino, N., Machon, N., Porcher, E., 2008. Plant and spider communities benefit differently from the
hedgerows in highway verges. Biological Conservation 141, 1581-1590.

Lindberg, N., Bengtsson, J., 2005. Population responses of oribatid mites and collembolans after drought. Applied Soil Ecology 28, 163-174.

Loranger, G., Bandyopadhyaya, I., Razaka, B., Ponge, J.F., 2001. Does soil acidity explain altitudinal sequences in collembolan communities? Soil Biology and Biochemistry 33, 381393.

McGill, B.J., Enquist, B.J., Weiher, E., Westoby, M., 2006. Rebuilding community ecology from functional traits. Trends in Ecology and Evolution 21, 178-185.Makkonen, M., Berg, M.P., van Hal, J.R., Callaghan, T.V., Press, M.C., Aerts, R., 2011. Traits explain the responses of a sub-arctic Collembola community to climate manipulation. Soil Biology and Biochemistry 43, 377-384.

Mebes, K.H., Filser, J., 1997. A method for estimating the significance of surface dispersal for population fluctuations of Collembola in arable land. Pedobiologia 41, 115-122.

Negri, I., 2004. Spatial distribution of Collembola in presence and absence of a predator. 36 Pedobiologia 48, 585-588.

37 Ozinga, W.A., Romermann, C., Bekker, R.M., Prinzing, A., Tamis, W.L.M., Schaminée, 38 J.H.J., Hennekens, S.M., Thompson, K., Poschlod, P., Kleyer, M., Bakker, J.P., van 
Groenendael, J.M., 2009. Dispersal failure contributes to plant losses in NW Europe. Ecology Letters 12, 66-74.

3 Pavoine, S., Vela, E., Gachet, S., de Belair, G., Bonsall, M.B., 2011. Linking patterns in 4 phylogeny, traits, abiotic variables and space: a novel approach to linking environmental 5 filtering and plant community assembly. Journal of Ecology 99, 165-175.

6 Ponge, J.F., Jabiol, B., Gégout, J.C., 2011. Geology and climate conditions affect more humus 7 forms than forest canopies at large scale in temperate forests. Geoderma 162, 187-195.

8 Ponge, J.F., Dubs, F., Gillet, S., Sousa, J.P., Lavelle, P., 2006. Decreased biodiversity in soil 9 springtail communities: the importance of dispersal and landuse history in heterogeneous 10 landscapes Soil Biology and Biochemistry 38, 1158- 1161.

11 Ponge, J.F., Gillet, S., Dubs, F., Fedoroff, E., Haese, H., Sousa, J.P., Lavelle, P., 2003. 12 Collembolan communities as bioindicators of land use intensification. Soil Biology and 13 Biochemistry 35, 813-826.

Ponge, J.F., 1980. Les biocénoses des Collemboles de la forêt de Senart. In: P. Pesson, (Ed.), Actualités d'Écologie Forestière,. Gauthier-Villars, Paris, France, pp151-176.

Ponge, J.F., 1983. Les collemboles indicateurs du type d'humus en milieu forestier. Résultats obtenus au Sud de Paris. Acta Oecologica, Oecologia Generalis 4, 359-374.

Ponge, J.F., 1993. Biocenoses of Collembola in atlantic temperate grass-woodland ecosystems. Pedobiologia 37, 223-244.

Ponge, J.F., 2000. Vertical distribution of Collembola (Hexapoda) and their food resources in organic horizons of beech forests. Biology and Fertility of Soils 32, 508-522.

Ponge, J.F., Chevalier, R., Loussot, P., 2002. Humus index: an integrated tool for the assessment of forest floor and topsoil properties. Soil Science Society of America Journal 66, 1996-2001.

Ponge, J.F., Salmon, S., 2013. Spatial and taxonomic correlates of species and species trait assemblages in soil invertebrate communities. Pedobiologia 56, 129-136.

Porco, D., Potapov, M., Bedos, A., Busmachiu, G., Weiner, W.M., Hamra-Kroua, S., Deharveng, L., 2012. Cryptic dversity in the ubiquist species Parisotoma notabilis (Collembola, Isotomidae): a long-used chimeric species? PLoS ONE 7, e46056.

Potapov, M., 2001. Synopses on Palaearctic Collembola. Volume 3. Isotomidae. Abhandlungen und Berichte des Naturkundemuseums Goerlitz 73, 1-603.

Prinzing, A., Reiffers, R., Braakhekke, W.G., Hennekens, S.M., Tackenberg, O., Ozinga, W.A., Schaminée, J.H.J., van Groenendael, J.M., 2008. Less lineages - more trait variation: phylogenetically clustered plant communities are functionally more diverse. Ecology Letters 11, 809-819.

R Development Core Team, 2010. R: a Language and Environment for Statistical Computing. R Foundation for Statistical Computing, Vienna, Austria. 
Rusek, J., 1989. Collembola and protura in a meadow-forest ecotone, In: Dallai, R. (Ed.), 3rd International Seminar on Apterygota. University of Siena, Siena, Italy, pp. 413-418.

Rusek, J., 1990. Collembola and other microarthropods. In: Osbornová J, Kovárová, Lepš J, Prach K (Eds) Succession in Abandonned Fields. Studies in Central Bohemia, Czechoslovakia. Kluwer Academic Publishers, Dordrecht, The Netherlands, pp. 55-58.

Rusek, J., 2007. A new classification of Collembola and Protura life forms, In: Tajovský, K., Schlaghamerský, J. \& Pižl, V. (Eds.), Contributions to Soil Zoology in Central Europe II. Academy of Sciences of the Czech Republic, Institute of Soil Zoology, České Budějovice, Czech Republic, pp. 109-115.

Rusek, J., Weyda, F., 1981. Morphology, ultrastructure and function of pseudocelli in Onychiurus armatus (Collembola, Onychiuridae). Revue d'Écologie et de Biologie du Sol 18, 127-133.

Salmon, S., 2004. The impact of earthworms on the abundance of Collembola: improvement

Salmon, S., Geoffroy, J.J., Ponge, J.F., 2005. Earthworms and collembola relationships: effects of predatory centipedes and humus forms. Soil Biology and Biochemistry 37, 487-495.

Salmon, S., Ponge, J., 2012. Species traits and habitats in springtail communities: a regional

Siepel, H., 1996. Biodiversity of soil microarthropods: the filtering of species. Biodiversity and Conservation 5, 251-260.

Thibaud, J.M., Schulz, H.J., da Gama Assalino, M.M., 2004. Synopses on Palaearctic Collembola Hypogastruridae. Abhandlungen und Berichte des Naturkundemuseums Goerlitz $75,1-287$.

Urban, M.C., Zarnetske, P.L., Skelly, D.K., 2013. Moving forward: dispersal and species interactions determine biotic responses to climate change. Annals of the New York Academy of Sciences 1297, 44-60.

Uriarte, M., Clark, J.S., Zimmerman, J.K., Comita, L.S., Forero-Montana, J., Thompson, J., 2012. Multidimensional trade-offs in species responses to disturbance: implications for diversity in a subtropical forest. Ecology 93, 191-205.

Vanbergen, A.J., Watt, A.D., Mitchell, R., Truscott, A.M., Palmer, S.C.F., Ivits, E., Eggleton, P., Jones, T.H., Sousa, J.P., 2007. Scale-specific correlations between habitat heterogeneity and soil fauna diversity along a landscape structure gradient. Oecologia 153, 713-725.

Vandewalle, M., de Bello, F., Berg, M.P., Bolger, T., Doledec, S., Dubs, F., Feld, C.K., Harrington, R., Harrison, P.A., Lavorel, S., da Silva, P.M., Moretti, M., Niemela, J., Santos, P., Sattler, T., Sousa, J.P., Sykes, M.T., Vanbergen, A.J., Woodcock, B.A., 2010. Functional traits as indicators of biodiversity response to land use changes across ecosystems and organisms. Biodiversity and Conservation 19, 2921-2947.

Vellend, M., 2010. Conceptual synthesis in community ecology. Quarterly Review of Biology 85, 183-206. 
1 Weiher, E., Freund, D., Bunton, T., Stefanski, A., Lee, T., Bentivenga, S., 2011. Advances, 2 challenges and a developing synthesis of ecological community assembly theory. 3 Philosophical Transactions of the Royal Society of London, Series B, Biological Sciences 4 366, 2403-2413.

5 Weiher, E., Keddy, P.A., 1995. Assembly rules, null models, and trait dispersion: new 6 questions from old patterns. Oikos 74, 159-164.

7 Zhu, K., Woodall, C.W., Ghosh, S., Gelfand, A.E., Clark, J.S., 2014. Dual impacts of climate 8 change: forest migration and turnover through life history. Global Change Biology 20, 251 9264. 
3 Fig. 1. Correspondence analysis showing the distribution and assembly of species (active

\section{Figure captions} variables) and environmental variables; a) Species and environmental variables along axes 1 and 2; b) Species and environmental variables along axes 2 and 3. See tables 1 and 2 for abbreviations.

Fig. 2. RLQ testing the direct relationships between climate (temperature and precipitation), altitude, vertical stratification, habitat closure and soil moisture, and traits. a) Environmental variables; b) Traits. Environmental variable classes were altitude: Alt.low: $<=50 \mathrm{~m}$, Alt.int: $50 \mathrm{~m}<\mathrm{x}<=100 \mathrm{~m}$, Alt.high $>100 \mathrm{~m}$; rainfall: Pre.Low $<=650 \mathrm{~mm}$, Pre.Int $650 \mathrm{~mm}<\mathrm{x}<=800 \mathrm{~mm}$, Pre.High $>800 \mathrm{~mm}$; temperature: Tem.Low $2.8^{\circ} \mathrm{C}<\mathrm{x}<8^{\circ} \mathrm{C}$, Tem.Int $8^{\circ} \mathrm{C}<\mathrm{x}<=11^{\circ} \mathrm{C}$, Tem.High $>11^{\circ} \mathrm{C}<\mathrm{x}<15^{\circ} \mathrm{C}$; habitat closure: close (H.Close), open (H.Open), intermediate (H.Int); stratification: epigeic levels of soil surface (S.Epi1), herb layers and boulders (S.Epi2), trees (S.Epi3), hemiedaphic and edaphic level (S.Soil) and soil and soil surface level (S.Epi.soil); hydromorpic (Hydro.1) and non-hydromorphic soils (Hydro.0). See Table 3 for abbreviations of species traits.

Fig. 3. RLQ testing the relationships between humus forms and soil types, habitat closure, soil moisture and traits. a) Environmental variables; b) Traits. Environmental variable classes were: habitat closure: close (H.Close), open (H.Open), intermediate (H.Int); stratification: epigeic levels of soil surface (S.Epi1), herb layers and boulders (S.Epi2), trees (S.Epi3), hemiedaphic and edaphic level (S.Soil) and soil and soil surface level (S.Epi.soil); hydromorpic (Hydro.1) and non-hydromorphic soils (Hydro.0); humus forms: mull (S.Mul), moder (S.Mod), mor (S.Mor), peat (S.Peat), mull or moder (S.MuMo), cultivated soil (S.Cult). See Table 3 for abbreviations of species traits. 
Table 1

Modalities, abbreviations, information level, and data type of environmental variables.

\begin{tabular}{|c|c|c|c|c|}
\hline $\begin{array}{l}\text { Environmental } \\
\text { variables }\end{array}$ & Modalities & $\begin{array}{l}\text { Abbreviations } \\
\text { for CA } \\
\text { graphics }\end{array}$ & $\begin{array}{l}\text { Information } \\
\text { level }(\%)\end{array}$ & $\begin{array}{l}\text { Data type } \\
\text { (units) }\end{array}$ \\
\hline \multirow{5}{*}{$\begin{array}{l}\text { Habitat } \\
\text { closure }\end{array}$} & Close habitat & Close & 100 & $0 / 1$ \\
\hline & Open habitat & Open & 100 & $0 / 1$ \\
\hline & Intermediate habitat & Int & 100 & $0 / 1$ \\
\hline & $\begin{array}{l}\text { Epigeic } 1 \text { (soil surface } \\
\text { and mosses) }\end{array}$ & Epi-1 & 100 & $0 / 1$ \\
\hline & $\begin{array}{l}\text { Epigeic } 2 \text { (herb layers } \\
\text { and boulders) }\end{array}$ & Epi-2 & 100 & $0 / 1$ \\
\hline \multirow[t]{6}{*}{ Stratification } & Epigeic 3 (trees) & Epi-3 & 100 & $0 / 1$ \\
\hline & $\begin{array}{l}\text { Soil (edaphic and/or } \\
\text { hemiedaphic) }\end{array}$ & Soil & 100 & $0 / 1$ \\
\hline & Hemiedaphic (litter) & Hemi & 84 & $0 / 1$ \\
\hline & $\begin{array}{l}\text { Edaphic }(\mathrm{A}, \mathrm{H}, \mathrm{B}, \mathrm{E} \\
\text { and layers deeper than } 3 \\
\mathrm{~cm})\end{array}$ & Eda & 84 & $0 / 1$ \\
\hline & Peat & Peat & 100 & $0 / 1$ \\
\hline & Mull & Mull & 65 & $0 / 1$ \\
\hline \multirow[t]{4}{*}{ Humus form } & Moder & Mod & 63 & $0 / 1$ \\
\hline & Mor & Mor & 63 & $0 / 1$ \\
\hline & Cultivated soil & Cult & 95 & $0 / 1$ \\
\hline & $\begin{array}{l}\text { Mean annual } \\
\text { temperature }\end{array}$ & Temp & 58 & value $\left({ }^{\circ} \mathrm{C}\right)$ \\
\hline \multirow{3}{*}{$\begin{array}{l}\text { Geoclimatic } \\
\text { features }\end{array}$} & Annual rainfall & Pre & 78 & $\begin{array}{l}\text { value } \\
\text { (mm/year) }\end{array}$ \\
\hline & Altitude & Alt & 80 & value (m) \\
\hline & Hydromorphy & Hydro & 100 & $0 / 1$ \\
\hline \multirow{4}{*}{$\begin{array}{l}\text { Soil } \\
\text { chemistry }\end{array}$} & Soil pH & $\mathrm{pH}$ & 61 & $0 / 1$ \\
\hline & Organic layer & Org & 49 & $0 / 1$ \\
\hline & Organo-mineral layer & $\mathrm{OM}$ & 47 & $0 / 1$ \\
\hline & $\mathrm{C} / \mathrm{N}$ ratio & $\mathrm{C} / \mathrm{N}$ & 42 & value \\
\hline
\end{tabular}


Table 2

Name, abbreviations for CA analysis, and number of observations of the 58 most commonly recorded collembolan species.

\section{Species name Abbreviation $\begin{gathered}\text { Number of } \\ \text { observations }\end{gathered}$ Species name Abbreviation $\begin{gathered}\text { Number of } \\ \text { observations }\end{gathered}$}

\begin{tabular}{|c|c|c|c|c|c|}
\hline $\begin{array}{l}\text { Allacma fusca } \\
\text { (Linnaeus, 1858) }\end{array}$ & Afu & 43 & $\begin{array}{c}\text { Mesaphorura } \\
\text { tenuisensillata } \\
\text { Rusek, } 1974\end{array}$ & Mte & 97 \\
\hline $\begin{array}{c}\text { Brachystomella } \\
\text { parvula } \\
\text { (Schäffer, 1896) }\end{array}$ & Bpa & 66 & $\begin{array}{c}\text { Mesaphorura } \\
\text { yosii (Rusek, } \\
1967)\end{array}$ & Муо & 106 \\
\hline $\begin{array}{c}\text { Ceratophysella } \\
\text { armata } \\
\text { (Nicolet, 1841) }\end{array}$ & Car & 57 & $\begin{array}{c}\text { Metaphorura } \\
\text { affinis (Börner, } \\
\text { 1902) }\end{array}$ & Maf & 20 \\
\hline $\begin{array}{c}\text { Ceratophysella } \\
\text { denticulata } \\
\text { (Bagnall, 1941) }\end{array}$ & Cde & 88 & $\begin{array}{c}\text { Micraphorura } \\
\text { absoloni (Börner, } \\
\text { 1901) }\end{array}$ & Mca & 87 \\
\hline $\begin{array}{l}\text { Dicyrtoma fusca } \\
\text { (Lubbock, 1873) }\end{array}$ & Dfu & 69 & $\begin{array}{c}\text { Micranurida } \\
\text { pygmaea } \text { Börner, } \\
1901\end{array}$ & Mpy & 255 \\
\hline $\begin{array}{c}\text { Dicyrtomina } \\
\text { minuta }(\mathrm{O} . \\
\text { Fabricius, } 1783)\end{array}$ & Dmi & 53 & $\begin{array}{c}\text { Neanura } \\
\text { muscorum } \\
\text { (Templeton, } \\
1835)\end{array}$ & $\mathrm{Nmu}$ & 147 \\
\hline $\begin{array}{c}\text { Entomobrya } \\
\text { multifasciata } \\
\text { (Tullberg, 1871) }\end{array}$ & Emu & 54 & $\begin{array}{c}\text { Oncopodura } \\
\text { crassicornis } \\
\text { Shoebotham, } \\
1911\end{array}$ & Ocr & 35 \\
\hline $\begin{array}{c}\text { Entomobrya } \\
\text { nivalis (Linnaeus, } \\
1758)\end{array}$ & Eni & 75 & $\begin{array}{c}\text { Orchesella cincta } \\
\text { (Linnaeus 1758) }\end{array}$ & Oci & 111 \\
\hline $\begin{array}{l}\text { Folsomia candida } \\
\text { Willem, } 1902\end{array}$ & Fca & 36 & $\begin{array}{l}\text { Paratullbergia } \\
\text { callipygos } \\
\text { (Börner, 1902) }\end{array}$ & Pca & 363 \\
\hline $\begin{array}{c}\text { Folsomia } \\
\text { manolachei } \\
\text { Bagnall, } 1939\end{array}$ & Fma & 268 & $\begin{array}{c}\text { Parisotoma } \\
\text { notabilis } \\
\text { (Schäffer, 1896) }\end{array}$ & Pno & 598 \\
\hline $\begin{array}{c}\text { Folsomia } \\
\text { quadrioculata } \\
\text { (Tullberg, 1871) }\end{array}$ & $\mathrm{Fqu}$ & 310 & $\begin{array}{c}\text { Pogonognathellus } \\
\text { flavescens } \\
\text { (Tullberg, 1871) }\end{array}$ & Pfl & 77 \\
\hline $\begin{array}{l}\text { Friesea mirabilis } \\
\text { (Tullberg, 1871) }\end{array}$ & Fmi & 103 & $\begin{array}{c}\text { Protaphorura } \\
\text { armata (Tullberg } \\
1869)\end{array}$ & Par & 161 \\
\hline $\begin{array}{l}\text { Friesea truncata } \\
\text { Cassagnau, } 1958\end{array}$ & Ftr & 239 & $\begin{array}{c}\text { Proisotoma } \\
\text { minima (Absolon } \\
\text { 1901) }\end{array}$ & Pmi & 66 \\
\hline $\begin{array}{l}\text { Heteromurus } \\
\text { major (Moniez, } \\
1889 \text { ) }\end{array}$ & Hma & 124 & $\begin{array}{c}\text { Proisotoma } \\
\text { minuta (Tullberg } \\
\text { 1871) }\end{array}$ & Pminu & 38 \\
\hline
\end{tabular}


Table 2 (continued)

\begin{tabular}{|c|c|c|c|c|c|}
\hline $\begin{array}{c}\text { Heteromurus } \\
\text { nitidus } \\
\text { (Templeton, } \\
\text { 1835) }\end{array}$ & Hni & 68 & $\begin{array}{c}\text { Pseudosinella } \\
\text { alba } \\
\text { (Packard, 1873) }\end{array}$ & Pal & 222 \\
\hline $\begin{array}{l}\text { Isotomiella minor } \\
\text { (Schäffer, 1896) }\end{array}$ & Imi & 642 & $\begin{array}{c}\text { Pseudachorutes } \\
\text { parvulus } \\
\text { Börner, } 1901\end{array}$ & Ppa & 96 \\
\hline $\begin{array}{c}\text { Isotomurus } \\
\text { palustris (Müller, } \\
1776)\end{array}$ & Ipa & 73 & $\begin{array}{c}\text { Pseudisotoma } \\
\text { sensibilis } \\
\text { (Tullberg, 1876) }\end{array}$ & Pse & 61 \\
\hline $\begin{array}{l}\text { Isotoma viridis } \\
\text { Bourlet, } 1839\end{array}$ & Ivir & 92 & $\begin{array}{c}\text { Sminthurinus } \\
\text { aureus } \\
\text { (Lubbock, 1862) }\end{array}$ & Sau & 208 \\
\hline $\begin{array}{l}\text { Lepidocyrtus } \\
\text { curvicollis } \\
\text { Bourlet, } 1839\end{array}$ & Lcu & 51 & $\begin{array}{l}\text { Sminthurinus } \\
\text { elegans } \\
\text { (Fitch, 1863) }\end{array}$ & Sel & 44 \\
\hline $\begin{array}{c}\text { Lepidocyrtus } \\
\text { cyaneus } \\
\text { Tullberg, } 1871\end{array}$ & Lcy & 119 & $\begin{array}{l}\text { Sminthurides } \\
\text { schoetti } \\
\text { Axelson, } 1903\end{array}$ & $\mathrm{Ssc}$ & 52 \\
\hline $\begin{array}{c}\text { Lepidocyrtus } \\
\text { lanuginosus } \\
\text { (Gmelin, 1788) }\end{array}$ & Lla & 459 & $\begin{array}{c}\text { Sminthurinus } \\
\text { signatus } \\
\text { (Krausbauer, } \\
1898 \text { ) }\end{array}$ & Ssi & 152 \\
\hline $\begin{array}{c}\text { Lepidocyrtus } \\
\text { lignorum } \\
\text { (Fabricius, 1793) }\end{array}$ & Lli & 207 & $\begin{array}{c}\text { Sphaeridia } \\
\text { pumilis } \\
\text { (Krausbauer, } \\
1898 \text { ) }\end{array}$ & Spu & 221 \\
\hline $\begin{array}{c}\text { Lepidocyrtus } \\
\text { violaceus } \\
\text { (Geoffroy, 1762) }\end{array}$ & Lvi & 30 & $\begin{array}{c}\text { Stenaphorurella } \\
\text { denisi } \\
\text { (Bagnall,1935) }\end{array}$ & Sde & 93 \\
\hline $\begin{array}{c}\text { Lipothrix } \\
\text { lubbocki } \\
\text { (Tullberg, 1872) }\end{array}$ & Llu & 69 & $\begin{array}{c}\text { Tomocerus minor } \\
\text { (Lubbock, 1862) }\end{array}$ & Tmi & 79 \\
\hline $\begin{array}{l}\text { Megalothorax } \\
\text { minimus } \\
\text { Willem, } 1900\end{array}$ & Mmi & 453 & $\begin{array}{c}\text { Willemia } \\
\text { anophthalma } \\
\text { Börner, } 1901\end{array}$ & Wan & 197 \\
\hline $\begin{array}{l}\text { Mesaphorura } \\
\text { hylophila } \\
\text { Rusek, } 1982\end{array}$ & Mhy & 161 & $\begin{array}{l}\text { Willemia denisi } \\
\text { Mills, } 1932\end{array}$ & Wde & 87 \\
\hline $\begin{array}{c}\text { Mesaphorura } \\
\text { italica } \\
\text { (Rusek, 1971) }\end{array}$ & Mit & 76 & $\begin{array}{c}\text { Willemia } \\
\text { intermedia Mills, } \\
1934\end{array}$ & Win & 38 \\
\hline $\begin{array}{c}\text { Mesaphorura } \\
\text { krausbaueri } \\
\text { Börner, } 1901\end{array}$ & $\mathrm{Mkr}$ & 174 & $\begin{array}{l}\text { Xenylla grisea } \\
\text { Axelson, } 1900\end{array}$ & $\mathrm{Xgr}$ & 45 \\
\hline $\begin{array}{c}\text { Mesaphorura } \\
\text { macrochaeta } \\
\text { Rusek, } 1976 \\
\end{array}$ & Mma & 513 & $\begin{array}{c}\text { Xenylla tullbergi } \\
\text { Börner, } 1903\end{array}$ & Xtu & 107 \\
\hline
\end{tabular}


Table 3

Modalities of traits, abbreviations for RLQ and models, type of data, number of species for each category of categorical and binary traits and mean* for discrete and continuous data.

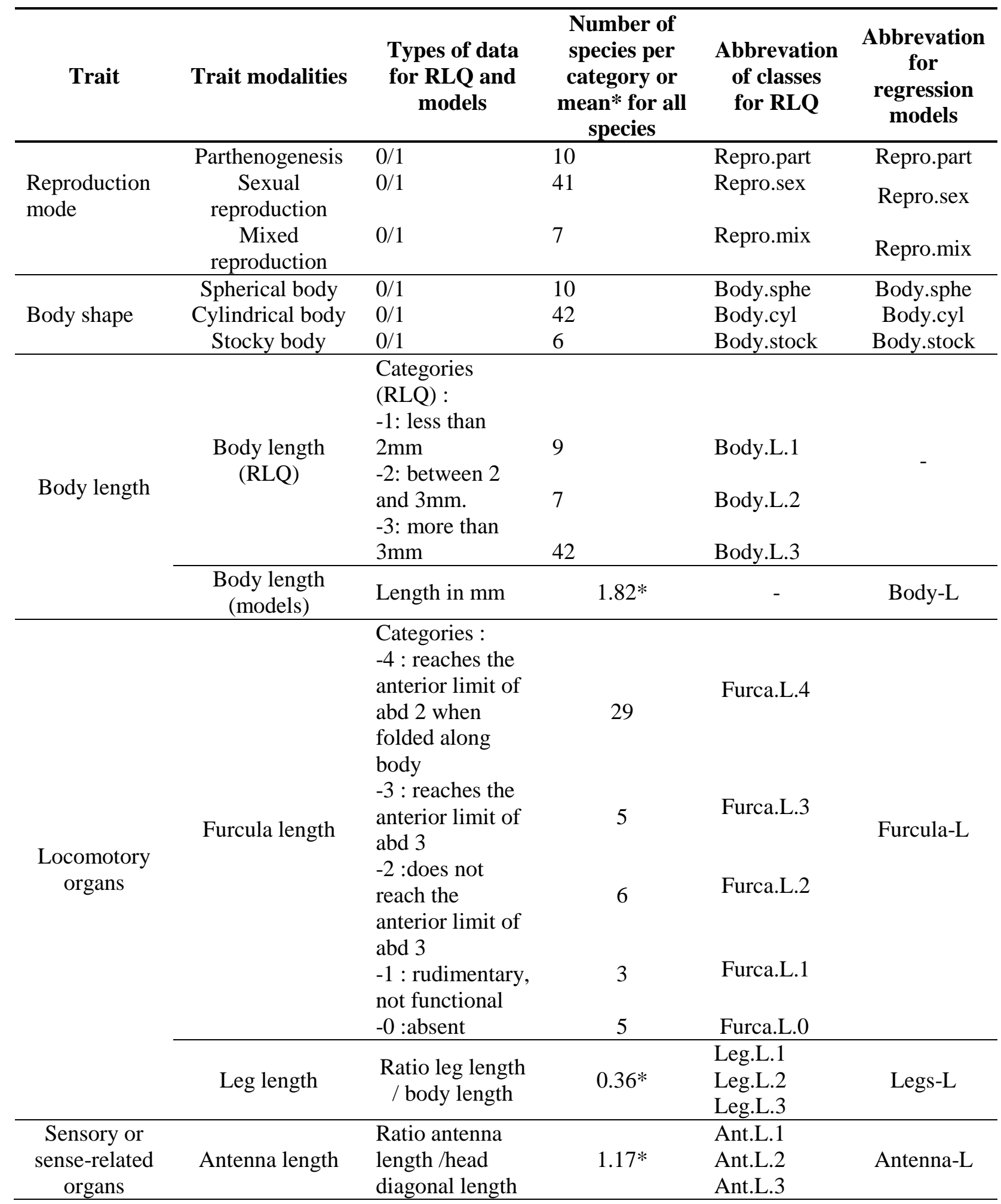


Table 3 (continued)

\begin{tabular}{|c|c|c|c|c|c|}
\hline Trait & Trait modalities & $\begin{array}{l}\text { Types of data } \\
\text { for RLQ and } \\
\text { models }\end{array}$ & $\begin{array}{l}\text { Number of } \\
\text { species per } \\
\text { category or } \\
\text { mean* for all } \\
\text { species } \\
\end{array}$ & $\begin{array}{l}\text { Abbrevation } \\
\text { of classes } \\
\text { for RLQ }\end{array}$ & $\begin{array}{l}\text { Abbrevation } \\
\text { for } \\
\text { regression } \\
\text { models }\end{array}$ \\
\hline \multirow{3}{*}{$\begin{array}{c}\text { Sensory or } \\
\text { sense-related } \\
\text { organs }\end{array}$} & Number of ocelli & $\begin{array}{l}\text { Number from } 0 \\
\text { to } 8\end{array}$ & $4-5^{*}$ & $\begin{array}{l}\text { Ocel.0 } \\
\text { Ocel.1 } \\
\text { Ocel.2 }\end{array}$ & Ocelli \\
\hline & $\begin{array}{l}\text { Max number of } \\
\text { PAO vesicles }\end{array}$ & $\begin{array}{l}\text { Number from } 0 \\
\text { to } 40\end{array}$ & $8^{*}$ & $\begin{array}{l}\text { PAO.ves.0 } \\
\text { PAO.ves. } 1 \\
\text { PAO.ves. } 2 \\
\end{array}$ & $\begin{array}{l}\text { PAO } \\
\text { vesicles-max }\end{array}$ \\
\hline & Trichobothria & $\begin{array}{l}\text { Absent:0 } \\
\text { Present :1 }\end{array}$ & 24 & $\begin{array}{l}\text { Tricho.0 } \\
\text { Tricho. } 1\end{array}$ & Tricho \\
\hline \multirow[b]{2}{*}{$\begin{array}{l}\text { Protective } \\
\text { features }\end{array}$} & Scales & $\begin{array}{l}\text { Absent:0 } \\
\text { Present :1 }\end{array}$ & 11 & $\begin{array}{l}\text { Scale. } 0 \\
\text { Scale. } 1 \\
\end{array}$ & Scales \\
\hline & Pigmentation & $\begin{array}{l}\text { Absent:0 } \\
\text { Present :1 } \\
\text { Presence } \\
\text { variable (RLQ } \\
\text { only) }\end{array}$ & 36 & $\begin{array}{l}\text { Pigment.0 } \\
\text { Pigment.1 } \\
\text { Pigment.var }\end{array}$ & Pigment \\
\hline $\begin{array}{l}\text { Defense } \\
\text { against } \\
\text { predators }\end{array}$ & Pseudocelli & $\begin{array}{l}\text { Absent:0 } \\
\text { Present :1 }\end{array}$ & 11 & $\begin{array}{l}\text { Pseudo.0 } \\
\text { Pseudo.1 }\end{array}$ & Pseudo \\
\hline
\end{tabular}




\section{Table 4}

Results of CCA followed with permutation tests with species occurrence as active variables and environmental factors as constraining variables. Humus form: Mull, Moder; Habitat closure: Open; Vertical stratification: Hemiedaphic, Epigeic-1, Epigeic-2, Epigeic-3; Hydromorphy, pH: soil pH, Climate: minimum Temperature and Precipitation.

\begin{tabular}{llcc}
\hline & & $\begin{array}{l}\text { Habitat closure-Vertical } \\
\text { stratification-Humus form- } \\
\text { Hydromorphy-Climate-pH }\end{array}$ \\
& & & \\
\hline \multirow{4}{*}{ Inertia } & Totale & 4.987 & 100 \\
& Constrained (\%) & 0.625 & 12.528 \\
& No-constrained (\%) & 4.362 & 87.472 \\
\hline Permutation & Permutation number & & 900 \\
test & Pseudo F & & 0.680 \\
& p-value & & $<0.0001$ \\
\hline
\end{tabular}


Table 5

Results of linear models ( $\mathrm{R}^{2}, \mathrm{~F}, \mathrm{p}$-value) and type III analysis of sum of squares (p-value) between discrete and continuous trait values, respectively and species occurrence in binary environmental variables or minimum values of continuous environmental variables (values in bold type indicate significant effect: $\mathrm{p}<0.05$; see Tables 1 and 3 for abbreviations).

\begin{tabular}{lcccccc}
\hline & Antenna-L & Furcula-L & Ocelli & Legs-L & $\begin{array}{c}\text { Log(Body- } \\
\text { L) }\end{array}$ & $\begin{array}{c}\text { Log(PAO } \\
\text { vesicles-max) }\end{array}$ \\
\hline $\mathrm{R}^{2}$ & 0.352 & 0.328 & 0.437 & 0.405 & 0.454 & 0.430 \\
$\mathrm{~F}$ & 5.543 & 6.337 & 10.085 & 6.937 & 4.983 & 7.710 \\
Pr $>$ F & $\mathbf{0 . 0 0 0}$ & $\mathbf{0 . 0 0 0}$ & $<\mathbf{0 . 0 0 0 1}$ & $<\mathbf{0 . 0 0 0 1}$ & $\mathbf{0 . 0 0 0}$ & $<\mathbf{0 . 0 0 0 1}$ \\
\hline Alt-min & & 0.359 & & 0.285 & 0.057 & 0.378 \\
Pre-min & 0.062 & & & & $\mathbf{0 . 0 4 1}$ & \\
Temp-min & $\mathbf{0 . 0 1 6}$ & $\mathbf{0 . 0 3 4}$ & $\mathbf{0 . 0 2 3}$ & 0.099 & 0.107 & $\mathbf{0 . 0 0 1}$ \\
Moder & & & & & 0.054 & \\
Mor & $\mathbf{0 . 0 0 9}$ & & & & & \\
Eda & $\mathbf{0 . 0 0 1}$ & & & $\mathbf{0 . 0 4 3}$ & & \\
Hemi & & & 0.809 & $\mathbf{0 . 0 0 4}$ & & 0.692 \\
Epi-1 & & $\mathbf{0 . 0 0 1}$ & $<\mathbf{0 . 0 0 0 1}$ & & $\mathbf{0 . 0 0 1}$ & $\mathbf{0 . 0 0 1}$ \\
Epi-2 & & & & $\mathbf{0 . 0 0 6}$ & $\mathbf{0 . 0 4 0}$ & \\
Epi-3 & & & & & $\mathbf{0 . 0 3 4}$ & \\
pH-min & 0.067 & 0.054 & 0.152 & & 0.081 & $\mathbf{0 . 0 0 1}$ \\
\hline
\end{tabular}


Table 6

Results of logistic models (Mc Fadden $\mathrm{R}^{2}, \mathrm{Khi}^{2}$, p-value) and type III analysis (p-value) between binary and qualitative trait values, respectively and species occurrence in binary environmental variables or minimum values of continuous environmental variables (values in bold type indicate significant effect: $\mathrm{p}<0.05$; see Tables 1 and 3 for abbreviations).

\begin{tabular}{|c|c|c|c|c|c|c|c|c|}
\hline & Scale & Pseudo & Repro.sex & Repro.part & Body.sphe & Body.cyl & Tricho & Pigment \\
\hline $\begin{array}{l}\mathrm{R}^{2} \\
\text { McFadden }\end{array}$ & 0.084 & 0.707 & 0.316 & 0.348 & 0.310 & 0.229 & 0.447 & 0.547 \\
\hline $\mathrm{Khi}^{2}$ & 4.756 & 39.842 & 22.207 & 18.572 & 16.556 & 15.211 & 35.152 & 49.431 \\
\hline p-value & 0.029 & $<0.0001$ & 0.000 & 0.001 & $<0.005$ & 0.019 & $<0.0001$ & $<0.0001$ \\
\hline Alt-min & & & & & & & 0.000 & \\
\hline Pre-min & & & & & & 0.533 & & \\
\hline Temp-min & & 0.000 & 0.030 & 0.030 & 0.077 & & 0.014 & \\
\hline Mull & & & & & & 0.666 & & \\
\hline Moder & & 0.623 & & & & & & \\
\hline Open & & & 0.217 & 0.698 & & & & \\
\hline Peat & & & & & & & 0.004 & \\
\hline Eda & 0.029 & & & & 0.172 & 0.068 & & 0.169 \\
\hline Hemi & & & 0.095 & & 0.002 & 0.010 & 0.148 & 0.295 \\
\hline Epi-1 & & $<0.0001$ & & 0.197 & 0.142 & & & $<0.0001$ \\
\hline Epi-2 & & & 0.003 & & 0.009 & 0.024 & 0.000 & \\
\hline Epi-3 & & & & 0.053 & & 0.070 & & \\
\hline $\mathrm{pH}-\min$ & & 0.001 & 0.281 & & & & & \\
\hline
\end{tabular}


Fig. 1

a)

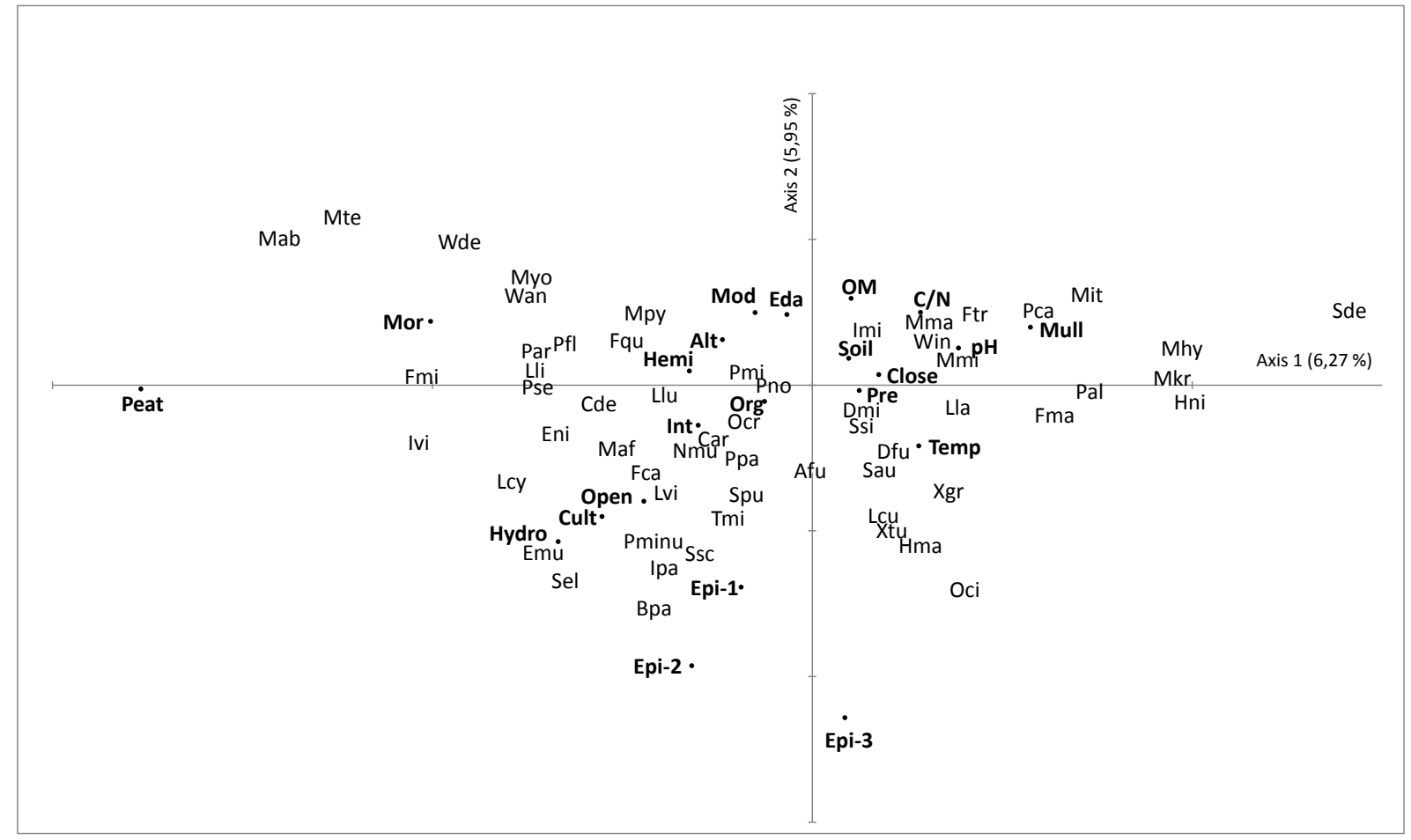

b)

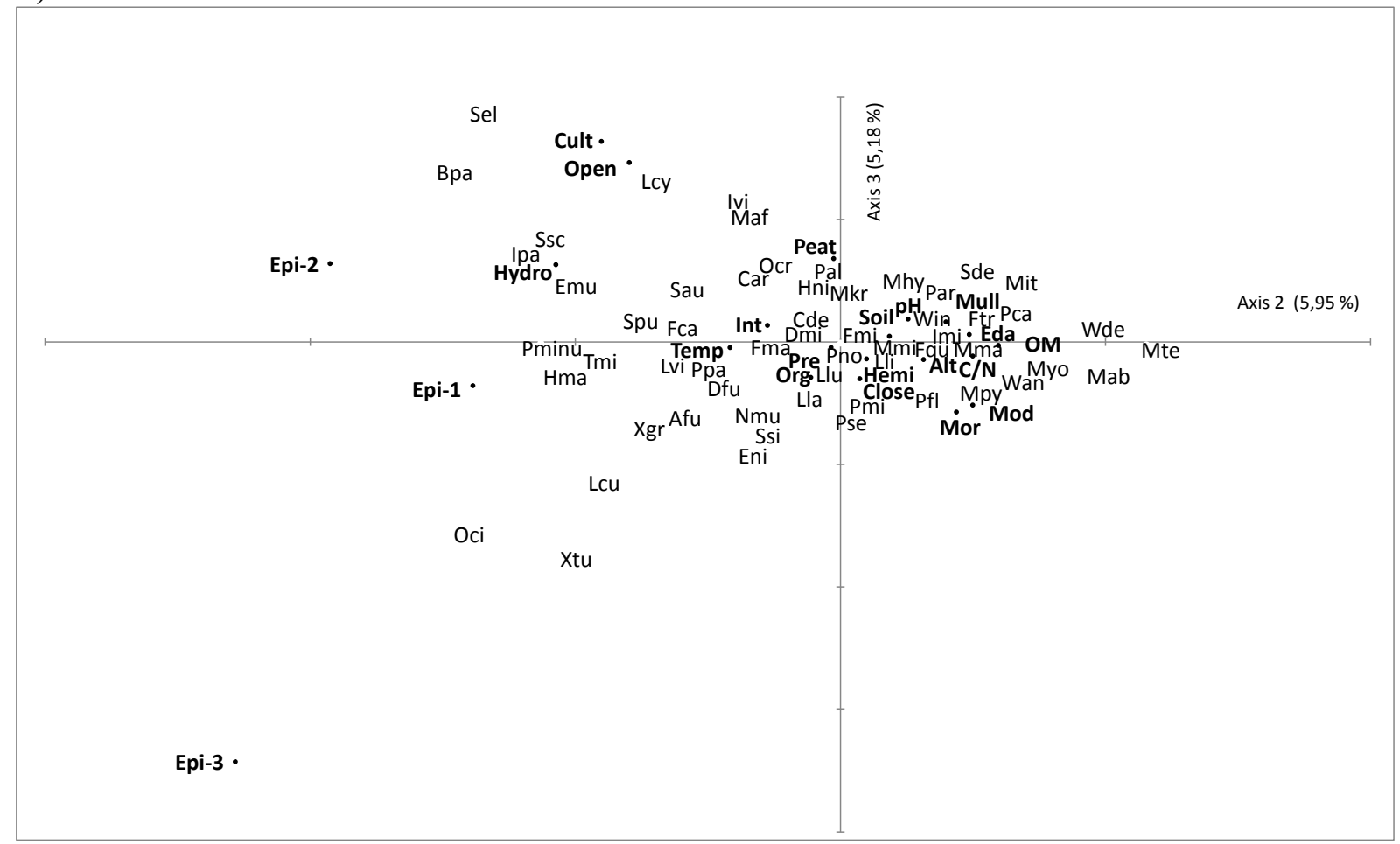


Fig. 2

a)

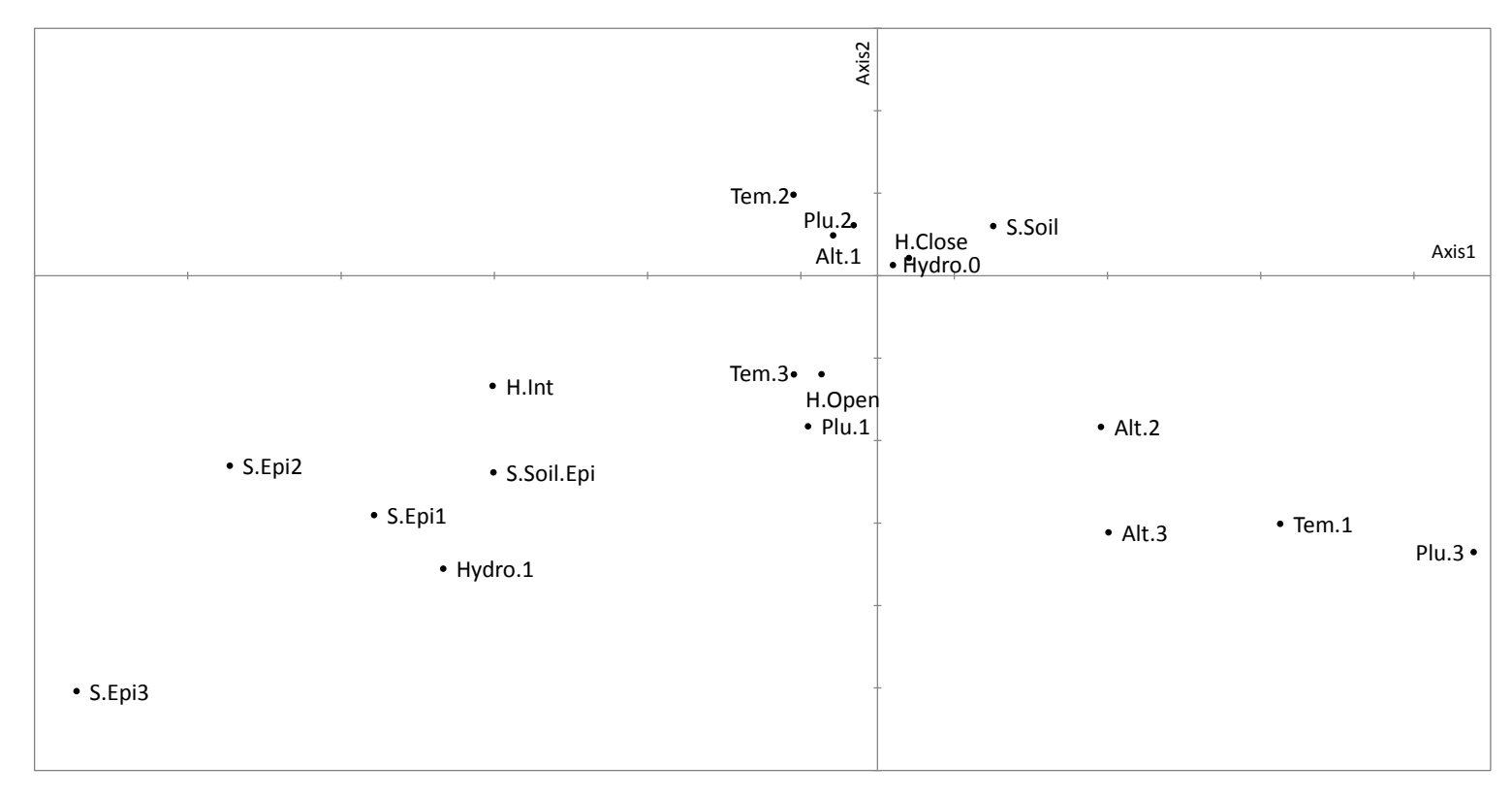

b)

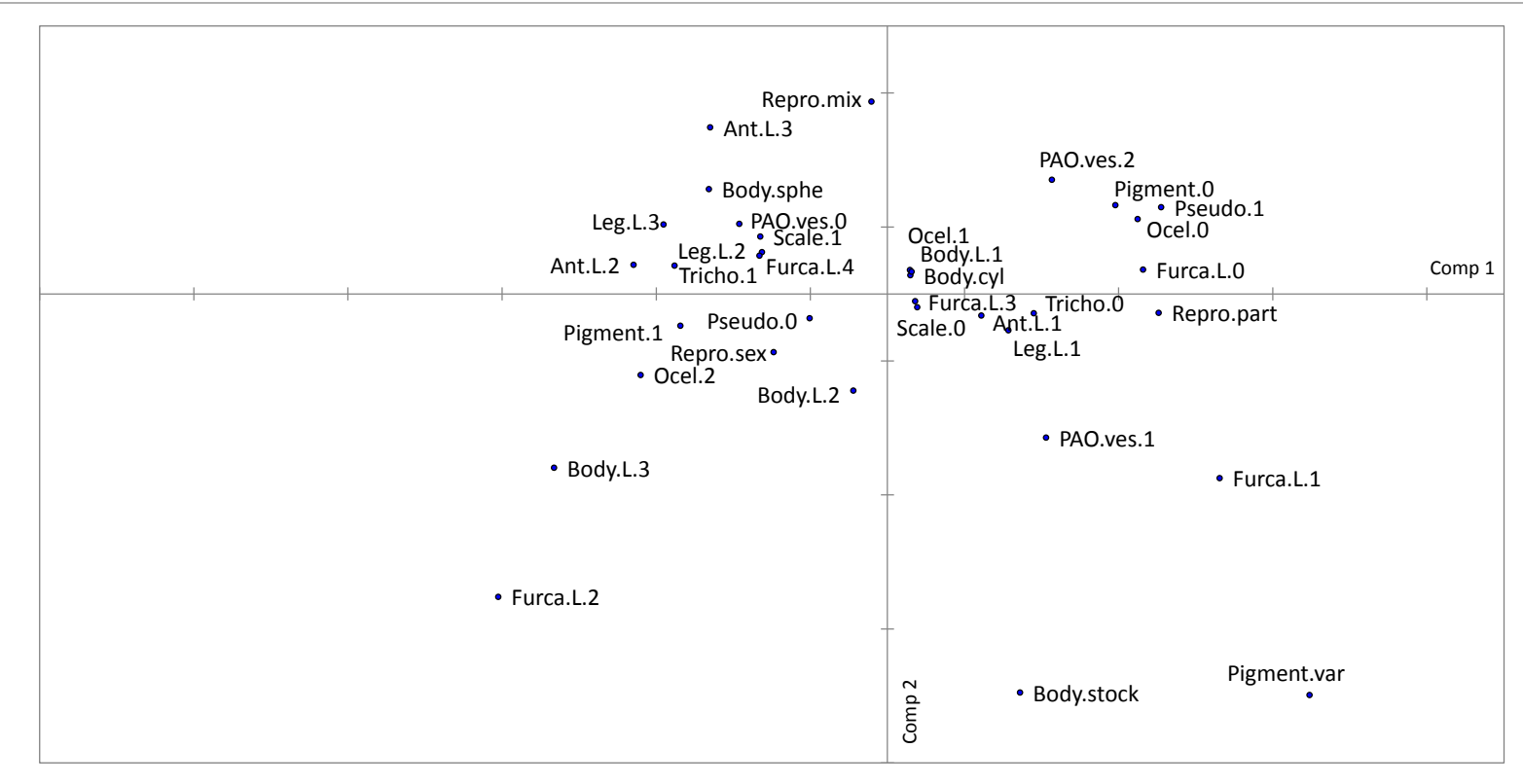


Fig. 3

a)

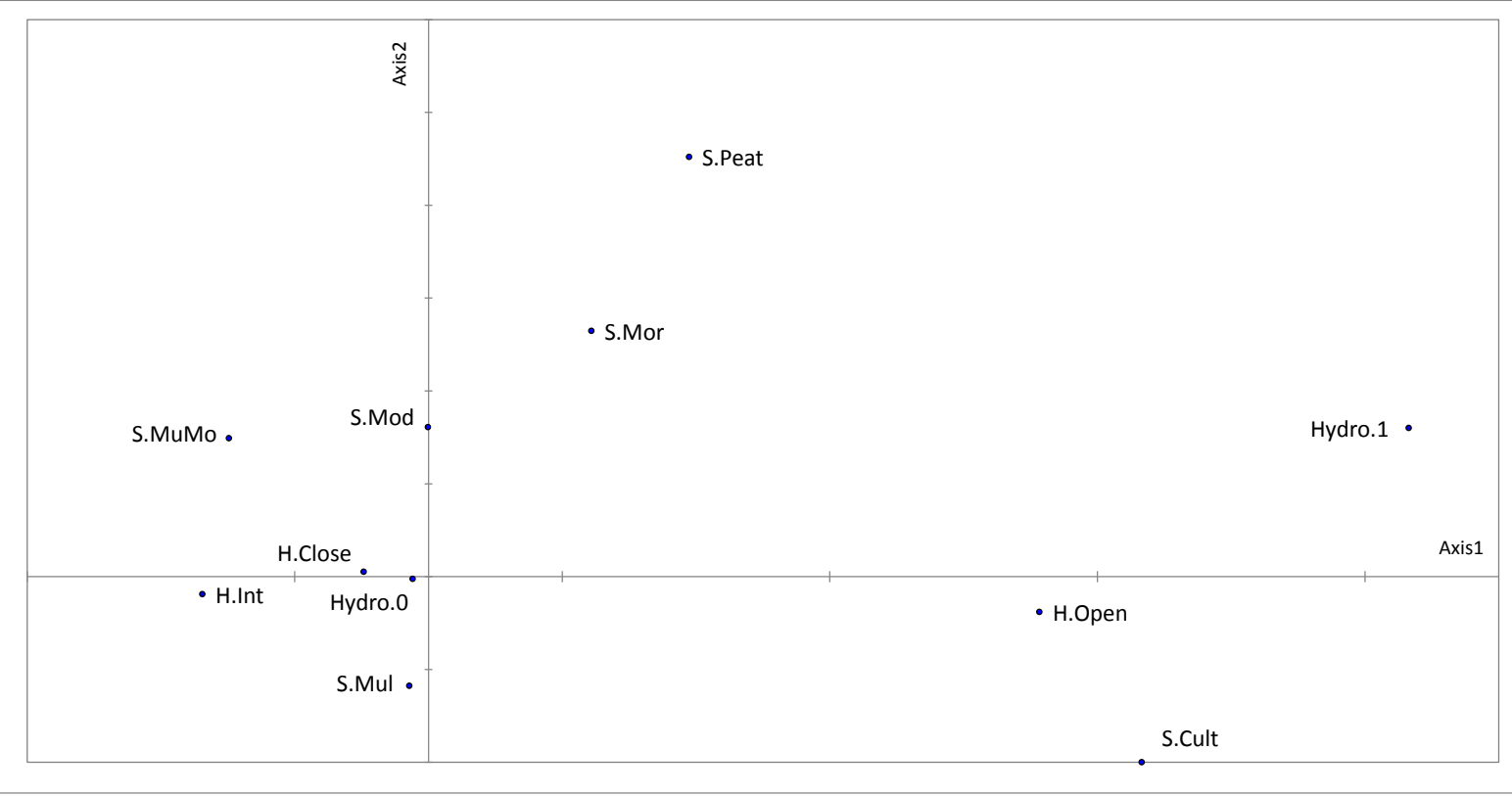

b)

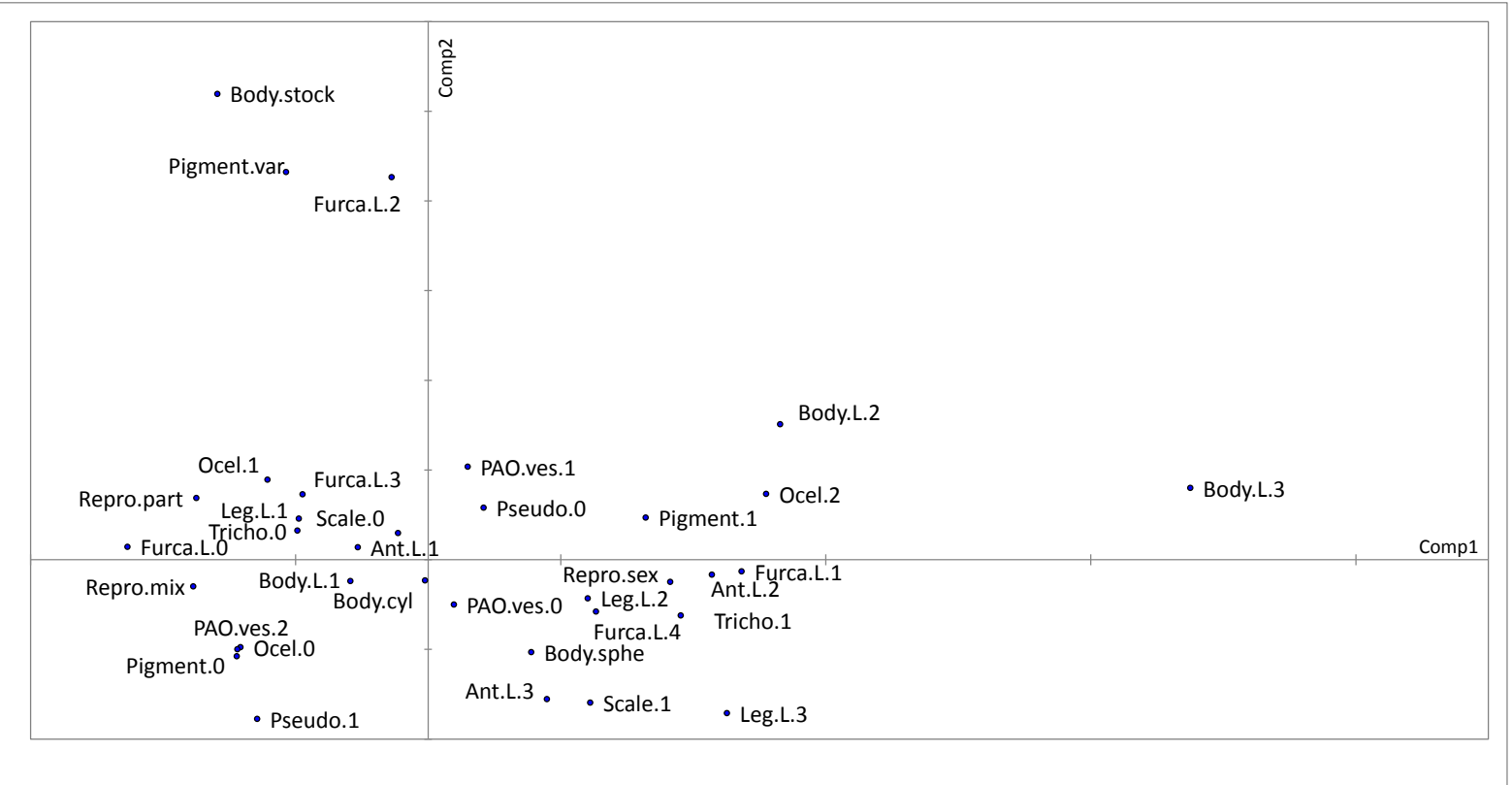




\section{Appendix 1}

References dealing with field studies on collembolan communities and used to compile occurrences of collembolan species in diverse habitats and the description of these habitats in Coltrait database.

Arpin, P., David, J.F., Guittonneau, G.G., Kilbertus, G., Ponge, J.F., G., V., 1986. Influence du peuplement forestier sur la faune et la microflore du sol et des humus. Revue d'Ecologie et de Biologie du Sol 23 (2), 119-153.

Arpin, P., Kilbertus, G., Ponge, J.F., Vannier, G., Verdier, B., 1985. Réactions des populations animales et microbiennes du sol à la privation des apports annuels de litière : exemple d'une rendzine forestière. Bulletins d'Ecologie 16 (1), 95-115.

Arpin, P., Ponge, J.-F., Dabin, B., Mori, A., 1984. Utilisation des nématodes Mononchida et des collemboles pour caractériser des phénomènes pédobiologiques. Revue d'Ecologie et de Biologie du Sol 21, 243-268.

Axelsson, B., Lohm, U., Persson, T., 1984. Enchytraeids, lumbricids and soil arthropods in a northern deciduous woodland - a quantitative study. Holarctic Ecology 7, 91-103.

Benito, J.C.S., Sanchez, M.J.L., 2000. Ecology of soil springtails (Collembola, Insecta) from pine woods and Rhododendron shrublands in the Central and Eastern Pyrenees (North Spain). Pedobiologia 44, 430-441.

Berg, M.P., Kniese, J.P., Bedaux, J.J.M., Verhoef, H.A., 1998. Dynamics and stratification of functional groups of micro- and mesoarthropods in the organic layer of a Scots pine forest . Biology and Fertility of Soils 26, 268-284.

Bernier, N., 1996. Altitudinal changes in humus form dynamics in a spruce forest at the montane level. Plant and Soil 178, 1-28.

Bonnet, L., Cassagneau, P., Deharveng, .L., 1976. Un exemple de rupture de l'équilibre biocénotique par déboisement: Les peuplements de Collemboles édaphiques du Piau d'Engaly (Hautes-Pyrénées). Revue d'Ecologie et de Biologie du Sol 13, 337-351.

Bruckner, A., Barth, G., Scheibengraf, M., 2000. Composite sampling enhances the confidence of soil microarthropod abundance and species richness estimates. Pedobiologia 44, 63-74.

Cassagne, N., Bal-Serin, M.C., Gers, C., Gauquelin, T., 2004. Changes in humus properties and collembolan communities following the replanting of beech forests with spruce. Pedobiologia 48, 267-276.

Cassagne, N., Gauquelin, T., Bal-Serin, M.C., Gers, C., 2006. Endemic Collembola, privileged bioindicators of forest management. Pedobiologia 50, 127-134. 
Cassagne, N., Gers, C., Gauquelin, T., 2003. Relationships between Collembola, soil chemistry and humus types in forest stands (France). Biology and Fertility of Soils 37, 355361.

Chauvat, M., Wolters, V., Dauber, J., 2007. Response of collembolan communities to landuse change and grassland succession. Ecography 30, 183-192.

Chauvat, M., Zaitsev, A.S., Wolters, V., 2003. Successional changes of Collembola and soil microbiota during forest rotation. Oecologia 137, 269-276.

Cortet, J., Poinsot-Balaguer, N., 1998. Collembola populations under sclerophyllous coppices in Provence (France): comparison between two types of vegetation, Quercus ilex L. and Quercus coccifera L. Acta Oecologica-International Journal of Ecology 19, 413-424.

Cragg, J.B., 1961. Some aspects of the ecology of moorland animals. Journal of Ecology 49, 477-506.

Da Gama, M.M., Sousa, J.P., Ferreira, C., Barrocas, H., 1997. Endemic and rare Collembola distribution in high endemism areas of south Portugal: A case study. European Journal of Soil Biology 33, 129-140.

Da Gama, M.M., Sousa, J.P., Vasconcelos, T.M., 1994. Comparison of Collembolan populations from portugese forests of Quercus Rotundifolia Lam. and Eucalyptus globulus Labill., In: Sacarrao, P.G.d.F. (Ed.), Arquivos do Museo Bocage, Lisboa., pp. 201-214. .

Deharveng, L., 1996. Soil collembola diversity, endemism and reforestation: a case study in the Pyrenees (France). Conservation Biology 10 (1), 74-84.

Detsis, V., Diamantopoulos, J., Kosmas, C., 2000. Collembolan assemblages in Lesvos, Greece. Effects of differences in vegetation and precipitation. Acta Oecologica-International Journal of Ecology 21, 149-159.

Dunger, W., Schutz, F.J., Zimdars, B., Hohberg, K., 2004. Changes in collembolan species composition in Eastern German mine sites over fifty years of primary succession. Pedobiologia 48, 503-517.

Frampton, G.K., Van den Brink, P.J., Wratten, S.D., 2001. Diel activity patterns in an arable collembolan community. Applied Soil Ecology 17, 63-80.

Fratello, B., Bertolani, R., Sabatini, M.A., Mola, L., Rassu, M.A., 1985. Effects of atrazine on soil microarthropods in experimental maize fields. Pedobiologia 28, 161-168.

Gillet, S., Ponge, J.F., 2005. Species assemblages and diets of Collembola in the organic matter accumulated over an old tar deposit. European Journal of Soil Biology 41, 39-44.

Hågvar, S., 1982. Collembola in Norwegian coniferous forest soils. I. Relations to plant communities and soil fertility. Pedobiologia 24, 255-296.

Hale, W.G., 1966. A population study of moorland collembola. Pedobiologia 6, 65-99.

Holmstrup, M., Maraldo, K., Krogh, P.H., 2007. Combined effect of copper and prolonged summer drought on soil Microarthropods in the field. Environmental Pollution 146, 525-533. 
Huhta, V., Ojala, R., 2006. Collembolan communities in deciduous forests of different origin in Finland. Applied Soil Ecology 31, 83-90.

Irmler, U., 2000. Changes in the fauna and its contribution to mass loss and $\mathrm{N}$ release during leaf litter decomposition in two deciduous forests. Pedobiologia 44, 105-118.

Kaczmarek, M., 1975. Influence of humidity and specific interactions on collembolan populations in a pine forest. In: Progress in soil zoology. Proceedings of the 5th International Colloquium on Soil Zoology of the International Society of Soil Science, Pragues, Czechoslovakia,17-22 septembre 1973. J. Vanek (Ed) Academia of Sciences, Pragues, pp 333-340.

Kampichler, C., 1990. Community structure and vertical distribution of Collembola and Cryptostigmata in a dry-turf cushion plant. Biology and Fertility of Soils 9, 130-134.

Kovac, L.u., Kosturova, N., Miklisova, D., 2005. Comparison of collembolan assemblages (Hexapoda, Collembola) of thermophilous oak woods and Pinus nigra plantations in the Slovak Karst (Slovakia). Pedobiologia 49, 29-40.

Liiri, M., Haimi, J., Setala, H., 2002. Community composition of soil microarthropods of acid forest soils as affected by wood ash application. Pedobiologia 46, 108-124.

Lindberg, N., Bengtsson, J., 2005. Population responses of oribatid mites and collembolans after drought. Applied Soil Ecology 28, 163-174.

Lindberg, N., Persson, T., 2004. Effects of long-term nutrient fertilisation and irrigation on the microarthropod community in a boreal Norway spruce stand. Forest Ecology and Management 188, 125-135.

Lopes, C.M., Dagama, M.M., 1994. The effect of fire on collembolan populations of mata da margaraca (portugal). European Journal of Soil Biology 30, 133-141.

Loranger, G., Bandyopadhyaya, I., Razaka, B., Ponge, J.-F., 2001. Does soil acidity explain altitudinal sequences in collembolan communities? Soil Biology and Biochemistry 33, 381393.

Maraun, M., Alphei, J., Beste, P., Bonkowski, M., Buryn, R., Migge, S., Peter, M., Schaefer, M., Stefan Scheu, S., 2001. Indirect effects of carbon and nutrient amendments on the soil meso- and microfauna of a beechwood. Biology and Fertility of Soils 34, 222-229.

Ojala, R., Huhta, V., 2001. Dispersal of microarthropods in forest soil. Pedobiologia 45, 443450.

Pichard, S., Massoud, Z., Elkaim, B., 1989. Ecologie des peuplements de Collemboles de quelques mares et de leurs abords en région parisienne. Revue d'Ecologie et de Biologie du Sol 26, 451-472.

Pitzalis, M., Luiselli, L., Bologna, M.A., 2010. Co-occurrence analyses show that non-random community structure is disrupted by fire in two groups of soil arthropods (Isopoda Oniscidea and Collembola). Acta Oecologica 36, 100-106. 
Ponge, J.-F., Arpin, P., Vannier, G., 1993. Collembolan response to experimental perturbations of litter supply in a temperate forest ecosystem. European Journal of Soil Biology 29, 141-153.

Ponge, J.-F., Gillet, S., Dubs, F., Fedoroff, E., Haese, H., Sousa, J.P., Lavelle, P., 2003. Collembolan communities as bioindicators of land use intensification. Soil Biology and Biochemistry 35, 813-826.

Ponge, J.F., 1980. Les biocénoses des Collemboles de la forêt de Senart. In Actualités d'écologie forestière P. Pesson, (Ed.) pp151-176, Gauthier-Villars, Paris.

Ponge, J.F., 1993. Biocenoses of Collembola in atlantic temperate grass-woodland ecosystems. Pedobiologia 37, 223-244.

Ponge, J.F., 2000b. Vertical distribution of Collembola (Hexapoda) and their food resources in organic horizons of beech forests. Biology and Fertility of Soils 32, 508-522.

Pozo, J., Selga, D., Simon, J.C., 1986. Studies on the collembolan populations of several plant communities of the Basque Country (Spain). Revue d'Ecologie et de Biologie du Sol 23, 215232.

Prat, B., Massoud, Z., 1980. Etude de la communauté des Collemboles dans un sol forestier. 1. Structure des peuplements. Revue d'Ecologie et Biologie du Sol 17, 199-216.

Querner, P., Bruckner, A., 2010. Combining pitfall traps and soil samples to collect Collembola for site scale biodiversity assessments. Applied Soil Ecology 45, 293-297.

Raschmanova, N., Kovac, L., Miklisova, D., 2008. The effect of mesoclimate an Collembola diversity in the Zadiel Valley, Slovak Karst (Slovakia). European Journal of Soil Biology 44, 463-472.

Rebecchi, L., Sabatini, M.A., Cappi, C., Grazioso, P., Vicari, A., Dinelli, G., Bertolani, R., 2000. Effects of a sulfonylurea herbicide on soil microarthropods. Biology and Fertility of Soils 30, 312-317.

Rusek, J., 1989. Collembola and protura in a meadow - forest ecotone, In: Dallai, R. (Ed.), 3rd International Seminar on Apterygota. University of Siena, Siena, Italy, Siena, Italy, pp. 413418.

Rusek, J., 1990. Collembola and other microarthropods. Osbornová J, Kovárová, Lepš J, Prach K (Eds) Succession in abandonned fields. Studies in Central Bohemia, Czechoslovakia. Kluwer Academic Publishers, Dordrecht, The Netherlands.

Syrek, D., Weiner, W.M., Wojtylak, M., Olszowska, G., Kwapis, Z., 2006. Species abundance distribution of collembolan communities in forest soils polluted with heavy metals. Applied Soil Ecology 31, 239-250.

Russell, D.J., Alberti, G., 1998. Effects of long-term, geogenic heavy metal contamination on soil organic matter and microarthropod communities, in particular Collembola. Applied Soil Ecology 9, 483-488. 
Shaw, P., Ozanne, C., Speight, M., Palmer, I., 2007. Edge effects and arboreal Collembola in coniferous plantations. Pedobiologia 51, 287-293.

Siira-Pietikainen, A., Haimi, J., Kanninen, A., Pietikainen, J., Fritze, H., 2001. Responses of decomposer community to root-isolation and addition of slash. Soil Biology and Biochemistry 33, 1993-2004.

Usher, M.B., 1970. Seasonnal and vertical distribution of a population of soil arthropods Collembola. Pedobiologia, 10, 224-236.

Wolters, V., 1998. Long-term dynamics of a collembolan community. Applied Soil Ecology 9, 221-227. 